\title{
"GIVE ME A BREAK! I COULDN'T HELP MYSELF!"?: REJECTING VOLITIONAL IMPAIRMENT AS A BASIS FOR DEPARTURE UNDER FEDERAL SENTENCING GUIDELINES SECTION 5K2.13
}

\author{
CARLOS M. PELAYo ${ }^{\dagger}$
}

\section{INTRODUCTION}

Child abusers, compulsive gamblers, kleptomaniacs, pedophiles, and others who know they are breaking the law but are unable to resist their impulses may get a break if they are sentenced in federal court. This is the result of a 1997 Third Circuit decision in which the court held that a defendant's "volitional impairment" may justify a reduction in sentencing, even if the defendant knew what she was doing, and knew that it was wrong. ${ }^{1}$ More specifically, the court ruled that a defendant's lack of self-control could serve as an independent basis for downward departure from the Federal Sentencing Guidelines (the "Guidelines") pursuant to section 5K2.13, which authorizes departures due to reduced mental capacity. ${ }^{2}$ As of November 1,1998 , the U. S. Sentencing Commission (the "Commission") officially endorsed this approach. ${ }^{3}$

$\dagger$ B.A. 1990, Boston College; M.A.L.D. 1992, The Fletcher School of Law and Diplomacy; J.D. Candidate 1999, University of Pennsylvania. I would like to thank Professors Stephen Morse and Leo Katz for their advice and assistance, and the members of the University of Pennsylvania Law Review for their time and effort in editing. I would also like to thank Rennae, my best friend and bride-to-be, for her constant love and support throughout this project. This Comment is dedicated to Martha Pelayo, my hero, my inspiration, and my beloved mother.

1 See United States v. McBroom, 124 F.3d 533, 544 (3d Cir. 1997) (holding that a downward departure may be justified for defendants who cannot control themselves); Matt Ackermann, Lack of Control May Warrant Shorter Term, Court Rules, N.J.L.J., Sept. 8, 1997, at 5 (reporting general concems over the Third Circuit's decision to consider volitional impairment as possible grounds for downward departure in sentencing).

${ }^{2}$ See McBroom, 124 F.3d at 544 ("We believe that a defendant's ability to control his or her own conduct is a relevant consideration when determining the defendant's eligibility for a downward departure pursuant to section 5K2.13."); see also U.S. SENTENCING GUIDELINES MANUAL § 5K2.13 (1994) ("If the defendant committed a non-violent offense while suffering from significantly reduced mental capacity not resulting from the use of drugs or other intoxicants, a lower sentence may be warranted to reflect the extent to which reduced mental capacity contributed to the commission of the offense ....").

${ }^{3}$ See U.S. Sentencing Commission, Sentencing Guidelines (May 18, 1998), Amendment No. 8, at 25-26, available in U.S. Sentencing Commission Homepage (last modified May 27, 
Consider the facts of the Third Circuit case. Kenneth McBroom, ${ }^{4}$ a practicing attorney, pled guilty to, and was convicted of, one count of possession of child pornography. ${ }^{5}$ McBroom had access to a wealth of pornographic images from the Internet, which he would download and store for his personal collection. ${ }^{6}$ About one month prior to the execution of the search warrant for his home that ultimately led to his arrest, McBroom learned that his on-line activities were under investigation by the FBI; yet, he did not cease or even curb his conduct. ${ }^{\text {? }}$

Following the entry of his plea, McBroom admitted that he fully understood the moral and legal implications of his activities at the time he engaged in them. ${ }^{8}$ Nevertheless, he moved in federal district court for a downward departure from his mandated sentence on the theory that he was volitionally impaired and therefore could not control himself. ${ }^{9}$ Reasoning that a departure pursuant to section $5 \mathrm{~K} 2.13$ is unavailable absent any indication that the defendant was unable to process information or to reason, ${ }^{10}$

1998) <http://www.ussc.gov/pdf/98amend2.pdf> (noting that the amendment to section $5 \mathrm{~K} 2.13$ adds an application note based on the decision in McBroom).

${ }^{4} \mathrm{McBroom}$ 's personal background adds profoundly disturbing overtones to the case. As a child, he suffered years of sexual abuse at the hands of his father, a trauma that undoubtedly altered the course of his life. Despite enjoying an outwardly successful career, McBroom endured bouts with drugs and alcohol as an adult. Several attempts at building a stable family life failed, each ending in divorce. He admitted to having a long-term fascination with peep shows and pornography as a result of his childhood abuse, and his states of depression have led him to take measures as drastic as self-mutilation. See McBroom, 124 F.3d at 535-37.

5 See id. at 534. McBroom's federal grand jury indictment initially charged him with three counts: "[O]ne count of knowingly transporting child pornography in violation of 18 U.S.C. $\$ 2252$ (a)(1), one count of knowingly receiving child pornography in violation of 18 U.S.C. $\$ 2252$ (a)(2), and one count of knowingly possessing child pornography in violation of 18 U.S.C. $\$ 2252$ (a)(4)." Id. at 537. McBroom pled guilty to count three. See id.

${ }^{6}$ See id. at 536-37. His collection included " "bestiality, masochism, bondage and every imaginable sexual fetish." Id. at 537 (quoting from McBroom's affidavit). About $25 \%$ of the images McBroom downloaded constituted child pornography. See id. at 537.

7 See id. (noting McBroom's activities despite his awareness of the FBI surveillance); see also United States v. McBroom, 991 F. Supp. 445, 449 (D.N.J. 1998) (reasoning, on remand, that "[e]ven when [McBroom] learned that the FBI was investigating him, he could not bring himself to simply delete the pornographic pictures from his computer").

${ }^{8}$ See McBroom, 124 F.3d at 541 ("McBroom does not argue that the district court erred when it found that he is able to absorb information in the usual way and to exercise the power of reason.").

${ }^{9}$ See id. at 534-35 ("McBroom contends that the abuse he endured as a child caused him to suffer from a significantly reduced mental capacity such that he felt compelled to possess child pornography ...."). McBroom argued that he suffered from reduced mental capacity within the meaning of section $5 \mathrm{~K} 2.13$ because he was diagnosed with an "Impulse Control Disorder" which made him out-of-control. See id. at 540.

${ }^{10}$ See id. (restating the district court's conclusion that "'a defendant able to absorb information in the usual way and to exercise the power of reason is not suffering from a significantly reduced mental capacity under U.S.S.G. § 5K2.13"' (quoting United States v. Johnson, 
the district court denied the motion. ${ }^{11}$ On appeal, McBroom argued that the sentencing judge took too narrow a view of that section and thereby improperly excluded certain individuals who, although able to absorb information in the usual way and to exercise the power of reason, are nevertheless incapable of controlling their behavior and conforming to the law. ${ }^{12}$ The Third Circuit agreed. ${ }^{13}$

The McBroom decision, and the wholesale endorsement of its logic by the Commission, ${ }^{14}$ are significant events because they raise many important

979 F.2d 396, 401 (6th Cir. 1992))). In fact, this is how most existing case law had interpreted section 5K2.13 prior to McBroom. See infra notes 190-201 and accompanying text (distinguishing the Third Circuit's holding from the treatment of volitional impairment by the D.C., Fourth, and Sixth Circuits).

${ }^{11}$ See McBroom, 124 F.3d at 540. It should be noted that McBroom's sentence had already been adjusted downward in accordance with his acceptance of responsibility. Moreover, although the pre-sentence report recommended an increase because the material involved a minor, the district court did not apply this upward adjustment. See id. at 537 \& n.3 (noting that the district court "granted a two-point downward adjustment for acceptance of responsibility," but did not apply the two-point upward adjustment, recommended in the pre-sentence report, for the possession of material involving minors under the age of 12).

${ }^{12}$ See id. at 541 (noting McBroom's claim that the term "significantly reduced mental capacity," as used in section $5 \mathrm{~K} 2.13$, should not exclude "individuals who, while able to absorb information in the usual way and to exercise the power of reason, are incapable of controlling their behavior and conforming it to the law").

${ }^{13}$ The court concluded that:

We believe that the following test adequately addresses our concerns that a sentencing court consider both a defendant's cognitive capacity and his or her volitional capacity when considering a downward departure pursuant to section 5K2.13: A person may be suffering from a 'reduced mental capacity' ... if either:

(1) the person is unable to absorb information in the usual way or to exercise the power of reason; or

(2) the person knows what he is doing and that it is wrong but cannot control his behavior or conform it to the law.

The first prong permits sentencing courts to consider defects of cognition. The second prong permits courts to consider defects of volition. Sentencing courts must consider both prongs before making a determination about a defendant's "reduced mental capacity."

Id. at 548 (emphasis added).

After creating this formulation, the Third Circuit vacated the district court's original sentence and remanded the case for resentencing. See id. at 551. On remand, the district court applied the new standard and concluded that McBroom's traumatic childhood experiences did warrant a downward departure. See United States v. McBroom, 991 F. Supp. 445, 447 (D.N.J. 1998). The original 15 -month sentence was reduced to six months in federal prison, plus three months of house arrest. See id. at 451; see also Jerry DeMarco, Sentence Reduced in Net Porn Case, RECORD (BERGEN, N.J.), Jan. 14, 1998, at A2.

14 The Commission has considered adding a volitional prong to section $5 \mathrm{~K} 2.13$ previously, but rejected the idea on multiple occasions. See, e.g., U.S. Sentencing Guidelines for United States Courts, 63 Fed. Reg. 602, 632 (1998) (proposing an amendment to section $5 \mathrm{~K} 2.13$ without adding a volitional prong). The Commission's sudden reversal appears to be based almost exclusively on the Third Circuit's reasoning in McBroom. See Written State- 
questions that have not been explored adequately within the context of federal sentencing: Given that volitional impairment is not considered for purposes of an affirmative insanity defense in federal cases, ${ }^{15}$ are there reasons to preclude it from being a factor in sentencing? Would allowing section 5K2.13 departures based on volitional impairment advance or hinder Congress's objectives in promulgating the Guidelines? Could such departures be justified under any moral theory of punishment or responsibility? If volitional impairment should not be a basis for section 5K2.13 departures, what alternatives are available in cases like McBroom? This Comment addresses these questions and others, including the most important and difficult question of all: What does it really mean to say that someone is volitionally impaired?

This Comment argues that it is incorrect to base section 5K2.13 departures on a defendant's volitional impairment. Most cases associated with volitional impairment, when properly analyzed, actually involve a perfectly functioning will and voluntary action. As a result, as long as the defendant is not irrational, unmitigated punishment is morally appropriate. Furthermore, allowing departures based on volitional impairment would frustrate Congress's objectives for the Guidelines, especially the objective of nationwide uniformity in sentencing. In light of these concerns, a better approach would be to allow section $5 \mathrm{~K} 2.13$ departures only under the traditional standard for reduced mental capacity, namely, when the defendant lacks the ability to reason and to distinguish right from wrong.

Part I summarizes the debate over volitional impairment within the context where it first gained national prominence-the federal insanity defense. Part II discusses the goals of federal sentencing generally and explores the extent to which considering volitional impairment as a factor for section 5K2.13 departures is compatible with these goals. Part III clarifies several major misconceptions regarding volitional impairment and develops a clearer understanding of what it truly means to say that one is "out-ofcontrol," or volitionally impaired. Finally, Part IV concludes by rejecting volitional impairment as a basis for section 5K2.13 departures. This Part proposes that, as long as defendants are able to rationally reflect upon their conduct, it is appropriate and necessary that they be given unmitigated sentences.

ments of Witnesses from Mar. 12, 1998 Public hearing on Proposed Amendments to the Sentencing Guidelines, available in U.S. Sentencing Commission Homepage (visited Feb. 25, 1999 ) <http//www.ussc.gov/hearings.htm> (indicating a conspicuous lack of public debate on the $M c B r o o m$ proposal for section 5K2.13).

${ }^{15}$ See infra note 28 and accompanying text (explaining that a volitional prong to the insanity defense has been rejected for federal purposes by the Insanity Defense Reform Act of $1984 \S 402(a), 18$ U.S.C. $\$ 17(1988)$ ). 


\section{THE BACKDROP: VOLITIONAL IMPAIRMENT AND THE INSANITY DEFENSE IN THE FEDERAL COURTS}

The concept of volitional impairment first gained prominence in the law as a key aspect of the alternative standard to the M'Naghten test for legal insanity. In that context, where its vices and virtues have been robustly debated, volitional impairment was ultimately rejected by the federal courts. Any inquiry into potentially valid grounds for such departures necessarily inherits much from this prior debate because departures pursuant to section $5 \mathrm{~K} 2.13$ are intended to mitigate for a defendant's reduced mental capacity. Accordingly, a brief review of the history of the insanity defense in the federal courts is a logical place to begin to determine the proper role for volitional impairment in federal sentencing.

The classic substantive test for insanity was established in 1843 in Daniel M'Naghten's Case. ${ }^{16}$ Under M'Naghten, legal insanity involves a disturbance or disease of the mind whereby the defendant did not appreciate the "nature and quality of the act he was doing; or, if he did know it, that he did not know he was doing what was wrong." standard, ${ }^{18}$ a defendant's lack of self-control is completely irrelevant to the determination of legal insanity, because only the cognitive ability to distinguish right from wrong matters.

Although it remains vibrant today, the M'Naghten test has endured much criticism. ${ }^{19}$ Some critics have observed, for example, that the human psyche is an "integrated entity of cognition and affect," and that other symptoms besides the inability to reason might constitute reduced mental capacity. ${ }^{20}$ Thus, in 1955, the American Law Institute (the "ALI") formulated a novel test for insanity that seemed to address some of M'Naghten's major perceived weaknesses. This new standard retained the cognitive analysis prescribed under $M^{\prime}$ Naghten, but it also added a so-called voli-

168 Eng. Rep. 718 (H.L. 1843).

${ }^{17}$ Id. at 722.

18 See SANFORd H. KADISH \& STEPHEN J. SCHUlhofer, CRIMINAL, LAW AND ITS PROCESSES 932 (6th ed. 1995) (characterizing the M'Naghten test as the "traditional test of legal insanity").

19 See Michael L. PERLIN, THE JURISPRUdenCE OF the INSANITY DEFENSE 78-84 (1994) (discussing attacks on the M'Naghten test).

${ }^{20}$ Id. at 82 (quoting Donald H.J. Herman \& Yvonne S. Sor, Convicting or Confining? Alternative Directions in Insanity Law Reform: Guilty but Mentally Ill Versus New Rules for Release of Insanity Acquittees, 1983 B.Y.U. L. Rev. 449, 512). Lianne C. Scherr, a nationally recognized psychiatrist and sentencing mitigation specialist, has enthusiastically embraced McBroom along these lines. See Alan Ellis, Let Judges Be Judges! Downward Departures After Koon, 12 CRIM. JUST. 49 (1998) (quoting Scherr, who noted that "[i]t is a relief to again be able to argue that some criminal behavior is the result of mental illness"). 
tional component which focused on the defendant's ability to control her behavior. $^{21}$

The ALI's new approach was incorporated into the Model Penal Code (the "MPC"). In jurisdictions that adopted the MPC, a defendant was not responsible by reason of insanity if, "as a result of mental disease or defect, he lacks substantial capacity either to appreciate the criminality [wrongfulness] of his conduct or to conform his conduct to the requirements of the law. ${ }^{22}$ Thus, an affirmative insanity defense could now be based either on the inability to reason, or, alternatively, on some inability to control one's actions.

The MPC test initially represented a viable alternative to the M'Naghten test. When a jury acquitted John W. Hinckley, Jr. in 1982 on the grounds of insanity, ${ }^{23}$ however, many jurisdictions balked. ${ }^{24}$ A period of intense nationwide pressure to limit the scope of the insanity defense ensued, ${ }^{25}$ and eventually the MPC test came under serious scrutiny. ${ }^{26}$ In 1984 , the Fifth Circuit concluded that, for purposes of pleading the insanity defense to federal offenses, volitional impairment should be completely disregarded. The court reasoned that the volitional prong of the MPC standard was inapplicable because "a majority of psychiatrists now believe that they do not possess sufficient accurate scientific bases for measuring a person's capacity for self-control or for calibrating the impairment of that capacity. $\$ 27$

${ }^{21}$ See Model Penal CODE $\$ 4.01$ (Tentative Draft No. 4, 1955) ("A person is not responsible for criminal conduct if at the time of such conduct he lacks substantial capacity either to appreciate the criminality of his conduct or to conform his conduct to the requirements of the law.").

${ }^{22} I d$. \$ 4.01(1) (emphasis added).

23 See United States v. Hinckley, 529 F. Supp. 520 (D.D.C. 1982) (finding Hinckley not guilty by reason of insanity for the attempted murder of then-President Ronald Reagan).

24 The acquittal of John Hinckley shocked and angered the American public. Three days after the jury's verdict, The New York Times referred to a "national reaction of stunned surprise" and a "cascade of public outrage." Stuart Taylor Jr., The Hinckley Riddle, N.Y. TMES, June 24, 1982, at D21 (reporting on the public furor following Hinckley's acquittal). This case "abruptly reversed" the trend in favor of the MPC approach.

${ }^{25}$ See PERLIN, supra note 19, at 13-30 (discussing the public furor over the Hinckley case during this period).

${ }^{26}$ Today, a majority of the states employ the M'Naghten test exclusively, but a sizable minority retain the MPC approach. See KADISH \& SCHULHOFER, supra note 18, at 948, 95355 (discussing legal developments in the aftermath of Hinckley's acquittal).

${ }^{27}$ United States v. Lyons, 731 F.2d 243, 248 (5th Cir. 1984) (en banc). This observation has since been affirmed by Professor Stephen Morse in an analysis of irresistible impulses and related crimes. He notes that:

No established metric exists to determine the magnitude of impulses, desires, or feelings. ... [T] [Te [psychological] studies do not address, and folk psychology does not know, whether and to what degree people are unable to refrain from acting. Neither in psychology [nor in philosophy] ... is there a reasonably uncontroversial 
Ultimately, Congress agreed with the Fifth Circuit. In 1984, it enacted the Insanity Defense Reform Act (the "IDRA"), ${ }^{28}$ which established the M'Naghten, or cognitive ability test, as the exclusive standard for legal insanity in federal cases. Today, if charged with a federal crime, a defendant may not raise volitional impairment as part of an affirmative insanity defense during the guilt phase of her trial.

\section{SENTENCING'S GOALS AND OBJECTIVES: VOLITIONAL IMPAIRMENT BEYOND THE INSANITY DEFENSE}

Although discarded for the purposes of a federal insanity defense, it does not necessarily follow that volitional impairment should play no role in sentencing. ${ }^{29}$ Instead, whether a defendant's ability to control her behavior should factor into sentencing decisions depends primarily upon Congress's purposes in enacting the Guidelines.

understanding of these matters.... The strongest contrary claims in the literature fail both conceptually and empirically.

Stephen J. Morse, Culpability and Control, 142 U. PA. L. REV. 1587, 1657-58 (1994).

${ }^{28}$ The IDRA was passed as part of the Comprehensive Crime Control Act of 1984. It states, in relevant part:

It is an affirmative defense to a prosecution under any Federal statute that, at the time of the commission of the acts constituting the offense, the defendant, as a result of a severe mental disease or defect, was unable to appreciate the nature and quality or the wrongfulness of his acts. Mental disease or defect does not otherwise constitute a defense.

18 U.S.C. § 17(a) (1988) (emphasis added).

${ }^{29}$ One commentator has recently argued that the interpretation of the insanity defense and the Guidelines are inextricably interrelated. She claims that the IDRA's rejection of volitional impairment during the guilt phase of federal criminal proceedings "evidences Congress" vehement objection to an analysis of a defendant's ability to exercise self-control." Kelly A. Herten, Comment, Downward Departure Under the Federal Sentencing: Lack of Self-Control as Grounds for Departure After United States v. McBroom, 102 DICK. L. REV. 649, 668 (1998). However, this argument exaggerates the logical connection between the IDRA's purposes and the goals and objectives in sentencing. It seems clear from the legislative history that Congress's main concern in passing the IDRA was that the volitional insanity defense cannot be reliably administered at trial, because of inherent problems with distinguishing those unable to conform to the law from those unwilling to do so. See S. Rep. No. 98-225, at 228 (1983), reprinted in 1984 U.S.C.C.A.N. 3182, 3410 ("The line between an irresistible impulse and an impulse not resisted is probably no sharper than that between twilight and dusk." (quoting the American Psychiatric Association Statement on the Insanity Defense, at 14 (Dec. 1982))); see also supra note 27. The main worry was the effect that this ambiguity might have on jurors. "However, because federal sentencing is entrusted to judges, not juries, the sentencing context does not implicate the administrability and reliability concerns as deeply as the trial context does." Criminal Law-Federal Sentencing Guidelines-Third Circuit Holds That Volitional Impairments Can Support a Claim of Diminished Mental Capacity-United States v. McBroom, 111 HARV. L. REV. 1122, 1125 (1998). 


\section{A. The Role of Sentencing and Departures Generally}

The Guidelines are the result of over twenty years of intense debate concerning the best system for punishing federal offenders. ${ }^{30}$ Prior to the Guidelines, an indeterminate sentencing and parole structure existed for most of the century that allowed judges broad discretion to tailor sentences based on the specific circumstances of each offender. Indeterminate sentencing was based primarily on the desire to rehabilitate offenders, thereby minimizing the risks of renewed criminal activity upon their unsupervised returns to society.

However, indeterminate sentencing had one major drawback. The system created significant disparities in federal sentencing practices nationwide. ${ }^{31}$ In 1984, Congress passed the Sentencing Reform Act ("SRA") 32 in response to this prevalent concern. The SRA was designed to "overhaul a system that was plagued by inequality and uncertainty."33

As part of the SRA, Congress created the Commission and authorized it to issue, and subsequently monitor, the Guidelines. ${ }^{34}$ Through this new system of determinate sentencing, Congress established a far more structured sentencing regime than had existed previously. Rehabilitation was no longer the sole objective to be achieved through sentencing. Rather, Congress provided for the development of the Guidelines to "further [all of] the basic purposes of criminal punishment: deterrence, incapacitation, just punishment, and rehabilitation..35

In furtherance of Congress's broad goals, the Commission stated its own objectives for sentencing reform, framed in terms of Congress's mandate: "provid[ing] certainty and fairness in ... sentencing, avoiding unwar-

${ }^{30}$ See MICHAEL TONRY, SENTENCING MATTERS 6-24 (1996) (detailing twenty-five years of fervor over sentencing); Theresa Walker Karle \& Thomas Sager, Are the Federal Sentencing Guidelines Meeting Congressional Goals?: An Empirical and Case Law Analysis, 40 EMORY L.J. 393, 393-94 (1991) (highlighting events in the sentencing debate over the past century).

${ }^{31}$ See Charles J. Ogletree, Jr., The Death of Discretion? Reflections on the Federal Sentencing Guidelines, 101 HARV. L. REV. 1938, 1944 (1988) ("The most frequent criticism of the broad discretion afforded federal judges in sentencing was that it led to disparate treatment for similarly situated individuals, a conclusion bolstered by a number of studies of sentencing patterns.").

${ }^{32}$ The SRA is codified principally at 18 U.S.C. $\$ \S 3551-85,3673,3742(1988)$, and 28 U.S.C. $\$ \S 991-98(1988)$.

33 Honorable Bruce M. Selya \& Matthew R. Kipp, An Examination of Emerging Departure Jurisprudence Under the Federal Sentencing Guidelines, 67 NOTRE DAME L. REV. 1, 3 (1991).

${ }^{34}$ The Guidelines are codified at 18 U.S.C. $\$ 3661$ (1988).

35 U.S. SENIENCING GUIDELINES MANUAL ch. 1, pt. A, Intro. ("The Statutory Mission") (1994) (codified at 18 U.S.C. $\$ 3553(a)(2)$ (1988)). 
ranted sentencing disparities among defendants with similar records who have been found guilty of similar criminal conduct[, and] maintaining sufficient flexibility to permit individualized sentences when warranted....,36

Uniformity in sentencing thus was an overarching objective of the new sentencing structure. This was not to be accomplished rigidly, or without exceptions. ${ }^{37}$ The actual operation of the Guidelines illustrates that both Congress and the Commission recognized the need for occasional variations in sentencing. For example, "sentencing courts are to treat each guideline as carving out a 'heartland,' [that is,] a set of typical cases embodying the conduct that each guideline describes." 38 Upward and downward adjustments within each range are allowed to account for certain pre-approved offender and offense characteristics. ${ }^{39}$

3628 U.S.C. $\$ 991(\mathrm{~b})(1)(B)(1988)$.

37 See U.S. SENTENCING GUIDELINES MANUAL ch. 1, pt. A, Intro. ("The Basic Approach (Policy Statement)") (1994) ("Relevant distinctions not reflected in the guidelines probably will occur rarely and sentencing courts may take such unusual cases into account by departing from the guidelines.").

38 Selya \& Kipp, supra note 33, at 11.

39 The mechanics of the actual sentencing process can be summarized as follows: At the core of the Guidelines is a sentencing grid, composed of forty-three offense ["base levels"] on the vertical axis and six criminal history categories on the horizontal axis. At the confluence of each offense level and criminal history category is a sentencing range. In determining the appropriate range to apply, the sentencing court must first look to the base level offense under which the defendant has been convicted. The base level offense will often call for upward or downward adjustments depending on the existence of specific offense characteristics (such as the amount of money involved in cases of fraud or the use of a firearm in a robbery). Id. at 6.

Next,... the [sentencing court] must determine whether additional base level adjustments are appropriate [in light of more offender-specific factors]. These [will] relate to (1) the victim's characteristics, (2) the defendant's role in the offense, (3) whether the defendant obstructed justice, (4) the incidence of multiple counts, and (5) whether the defendant accepted responsibility for his actions. ...

Equipped with the defendant's total base offense level and criminal history category, [the court may determine the applicable sentencing range]. If the interim calculations were properly performed, the imposition of a final sentence within the sentencing range may not be reviewed on appeal.

In deciding the actual sentence [within the applicable range] to be imposed, [however,] the court must consider a number of [additional] factors prescribed by Congress. They include the seriousness of the offense, deterrence, public protection,... policy statements of the Sentencing Commission, and avoidance of unwarranted disparities in sentencing. Having [considered all of] these factors, the court [will] select a sentence from within the sentencing range.

Id. at 6-8 (footnotes omitted).

If ever warranted by unusual circumstances, a sentencing court may impose a sentence outside the range prescribed by the guidelines. This practice is called a departure. Depending on whether the Commission has taken a position on the particular circumstances involved, departures may be either "guided" or "unguided" by official policy statements. See id. at 1112. 
When a sentencing court is faced with a truly atypical case, a departure may be warranted. Departures constitute a sentence imposed outside the prescribed sentencing range. They are justified under the principle that leniency ${ }^{40}$ is appropriate in such cases, and are generally available only when "there exists an aggravating or mitigating circumstance of a kind, or to a degree, not adequately taken into consideration by the Sentencing Commission in formulating the Guidelines." 41

Departures illustrate that the concepts of leniency and mitigation are not inconsistent with determinate sentencing under the Guidelines. The only prerequisites for a valid departure are that the purported grounds for departing have not been specifically precluded by the Commission, and that such grounds serve Congress's overall objectives in enacting the Guidelines. Accordingly, the Guidelines detail several factors that the Commission has adequately considered and thereby excluded as valid grounds for departure, ${ }^{42}$ as well as other factors that it has yet to fully develop and which therefore remain "unguided., $\$ 4$

Until recently, trial court discretion regarding departures was limited in many jurisdictions. In some circuits, the trial courts' discretion was limited to merely proposing bright-line rules to the circuit court which, if adopted, became standards for future operation - the equivalent of judicial amendments to the Guidelines. ${ }^{44}$ In 1996, the Supreme Court decided Koon $v$. United States, ${ }^{45}$ which for the first time provided guidance to the district courts regarding their discretion to grant departures. Koon requires that each case be decided on its individual merits. Proposed departures may no longer be categorically restricted unless the Guidelines themselves have

${ }^{40}$ In McBroom, for example, the Third Circuit contended that the principles of leniency that underlie sentencing departures for cognitive impairments "apply with equal force to ... those who cannot control their behavior." 124 F.3d 548, 533 (3d Cir. 1997) (citing United States v. Weddle, 30 F.3d 532, 540 (4th Cir. 1994)).

${ }^{41} 18$ U.S.C. $\$ 3553$ (b) (1988). The SRA limits the sentencing court's ability to examine what cases are "of a kind" or "to a degree not adequately taken into consideration." In making this review, a sentencing court may only look to the Guidelines themselves, policy statements, and official commentary by the Commission. See id.; see also U.S. SENTENCING GUIDELINES MANUAL $\S 5 \mathrm{~K} 2.0$, Other Grounds for Departure (Policy Statement) (providing an overview of sentencing departure decisions).

${ }^{42}$ See, e.g., U.S. SENTENCING GuDELINES MANUAL $\S \S 5 H 1.1-5 H 1.10$ (1994) (noting that race, sex, national origin, and religion can never be bases for departure, and suggesting that age and family ties, among other factors, are generally not relevant).

${ }^{43}$ See, e.g., id. $\S \S 5 \mathrm{~K} 2.1-5 \mathrm{~K} 2.16$ (listing numerous factors that may provide a proper basis for departure).

44 See, e.g., United States v. Higgins, 967 F.2d 841, 845 (3d Cir. 1992); United States v. Wogan, 938 F.2d 1446, 1448-49 (1st Cir. 1991); United States v. Joyner, 924 F.2d 454, $459-$ 61 (2d Cir. 1981).

45 518 U.S. 81 (1996). 
specifically precluded them as not involving an appropriate sentencing consideration. ${ }^{46}$ After Koon, sentencing judges have greater discretion to consider departures than ever before under a determinate sentencing regime.

\section{B. Section 5K2.13: Reduced Mental Capacity Departures}

Section 5K2.13 of the Guidelines provides one potential basis for departures that the Commission has not adequately considered; departures under this section are unguided. It authorizes departures from the prescribed sentencing range where a defendant can demonstrate that she suffers from "significantly reduced mental capacity.",47

Section $5 \mathrm{~K} 2.13$ was recently revised primarily to address a circuit split regarding whether this particular type of departure is precluded if the defendant committed a "crime of violence," as that term is defined in the career offender guideline. ${ }^{48}$ It now provides as follows:

A sentence below the applicable guideline range may be warranted if the defendant committed the offense while suffering from a significantly reduced mental capacity. However, the court may not depart below the applicable guideline range if (1) the significantly reduced mental capacity was caused by voluntary use of drugs or other intoxicants; (2) the facts and circumstances of the defendant's offense indicate a need to protect the public because the offense involved actual violence or a serious threat of violence; or (3) the defendant's criminal history indicates a need to incarcerate the defendant to protect the public. If a departure is warranted, the extent of the departure should reflect the extent to which the reduced mental capacity contributed to the commission of the offense. ${ }^{49}$

The Commission did not stop its overhaul of section 5K2.13 there, however. For the first time, the Commission added an application note to this section. Because the standard "significantly reduced mental capacity" had not previously been defined by the Guidelines, ${ }^{50}$ this application note

${ }^{46}$ See id. at 94 ("[T] (The [Sentencing Reform] Act authorizes district courts to depart in cases that feature aggravating or mitigating circumstances of a kind or degree not adequately taken into consideration by the Commission.").

47 U.S. SENTENCING GUIDELINES MANUAL § 5K2.13 (1994)

48 See U.S. Sentencing Commission, Sentencing Guidelines (May 18, 1998), Amendment No. 8, at 25, available in U.S. Sentencing Commission Homepage (last modified May 27, 1998) <http://www.ussc.gov/pdf/98amend2.pdf> (addressing the circuit split that existed between the Sixth, Seventh, and Ninth Circuits on the one hand, and the D.C., Third, and Fourth Circuits on the other, prior to the recent amendments to section $5 \mathrm{~K} 2.13$ ).

${ }^{49}$ Id. at 26-27; see also U.S. SENTENCING GUIDELINES MANUAL $§ 5 \mathrm{~K} 2.13$ (LEXIS through Nov. 12, 1998 Amendments).

${ }^{50}$ United States v. McBroom, 124 F.3d 533, 544.48 (3d Cir. 1997) (discussing the various interpretations of "significantly reduced mental capacity"). 
was specifically intended to define that term in accord with the decision in McBroom. ${ }^{51}$ The application note provides:

For purposes of this policy statement-

"Significantly reduced mental capacity" means the defendant, although convicted, has a significantly impaired ability to (A) understand the wrongfulness of the behavior comprising the offense or to exercise the power of reason; or (B) control behavior that the defendant knows is wrongful. ${ }^{52}$

Reduced mental capacity under the previous section $5 \mathrm{~K} 2.13^{53}$ had been traditionally established by showing that the defendant was unable to reason or to absorb information in the usual way. ${ }^{54}$ Yet, the Commission has decided specifically to include both cognitive and volitional types of impairments within the scope of the new section 5K2.13.

The United States Supreme Court has upheld the primacy of the Commission over the federal courts in determining the proper grounds for departure under the Guidelines' ranges. ${ }^{55}$ Moreover, there is no conceptual barrier that prohibits establishing the existence of reduced mental capacity through volitional impairment. The fact that this standard has been rejected for purposes of the federal insanity defense ${ }^{56}$ is not necessarily conclusive evidence that it should not be applied in sentencing. Indeed, determining a defendant's appropriate punishment is an analytical question distinct from deciding guilt.

51 See Amendment No. 8 to Sentencing Guidelines, at 26 (noting that "[t]he amendment also adds an application note that defines 'significantly reduced mental capacity' in accord with the decision in United States v. McBroom").

${ }_{52} \mathrm{Id}$. at 27 .
${ }^{53}$ Section $5 \mathrm{~K} 2.13$ previously provided:

If the defendant committed a non-violent offense while suffering from significantly reduced mental capacity not resulting from voluntary use of drugs or other intoxicants, a lower sentence may be warranted to reflect the extent to which reduced mental capacity contributed to the commission of the offense, provided that the defendant's criminal history does not indicate a need for incarceration to protect the public.

U.S. SENTENCING GUIDELINES MANUAL § 5K2.13 (1994).

${ }^{54}$ This is essentially the $M^{\prime}$ Naghten, or cognitive ability, test for insanity. See supra Part I (describing the M'Naghten cognitive ability test which questions the ability to distinguish right from wrong); see also supra note 10 and accompanying text (noting that all circuits that had ruled on sentencing departures pursuant to section $5 \mathrm{~K} 2.13$ prior to $M c B r o o m$ have applied the cognitive ability standard).

55 See Koon v. United States, 518 U.S. 81, 106 (1996) (noting that "Congress did not grant federal circuits authority to decide what sorts of sentencing considerations are inappropriate," and indicating that such decisions are up to the Sentencing Commission).

${ }^{56}$ See supra note 28 and accompanying text (establishing that a defendant may not raise volitional impairment as part of a federal insanity defense). 
Thus, understanding why the Commission's decision to endorse the Third Circuit's logic in McBroom is misguided does not depend on any lack of authority or logical weakness in the Commission's approach. Rather, the real concern involves the many practical problems that flow from the severe confusion that currently abounds regarding what it means to be "volitionally impaired." ${ }^{\text {} 57}$ In most cases, the term is used carelessly to pardon conduct that is not truly involuntary action, and that is therefore unworthy of any mercy. Accordingly, before we can effectively dismiss volitional impairment as a valid basis for section $5 \mathrm{~K} 2.13$ sentencing departures, it is necessary to develop a better understanding of what it truly means to be volitionally impaired.

In order to clarify the concept of volitional impairment, a key threshold issue is whether a defendant who asserts this impairment deserves leniency in the same way that an irrational, or cognitively impaired, defendant deserves such treatment. This issue, in turn, depends upon two considerations: whether volitional impairment truly leads to involuntary action, as the term suggests, and whether expanding the standard for section $5 \mathrm{~K} 2.13$ departures to include a volitional factor would advance Congress's main objectives for sentencing reform. ${ }^{58}$

\section{UNDERSTANDING VOLITIONAL IMPAIRMENT: WHAT IT MEANS TO BE "OUT OF CONTROL"}

In colloquial terms, to say that a defendant was volitionally impaired is generally understood to mean that she could not control her behavior in conformity with the law. Usually, the desired legal consequence of this verbal association is mitigation, which is warranted because culpability should not be ascribed when an agent has acted involuntarily. However, cases involving real involuntary action actually represent a small number of circumstances. Defendants like McBroom, whose conduct, upon close examination, can be shown to be completely voluntary, actually strive to "borrow excusing force"59 from that limited class of cases.

There are several conceptual problems with this line of reasoning. The most obvious is simply that defendants such as McBroom are able to appreciate fully, before they act, the legal and moral consequences of their actions. Further, such defendants are under no readily apparent compulsion when they decide to act. Thus, their conduct reasonably appears to be com-

57 See infra Part IV.A (discussing these practical problems).

58 See supra note 35 and accompanying text (listing deterrence, incapacitation, just punishment, and rehabilitation as Congress's sentencing objectives).

59 Morse, supra note 27, at 1591. 
pletely voluntary to the casual observer. Nevertheless, volitional impairment continues to be asserted under four major theories, each of which purports to establish that the defendant was, in fact, out-of-control: (1) Determinism or Universal Causation, (2) Defect of the Will, (3) Irresistible Impulse, and (4) Hard Choice. Ultimately, each of these theories fails to prove that so-called "volitionally impaired" defendants lack self-control in any meaningful way for sentencing purposes.

\section{A. A Paradigm for Voluntary and Involuntary Action}

The following Subparts of this Comment refer to cases of true, or uncontroversial, involuntary action, as opposed to voluntary action that is colloquially couched as involuntary by the label "volitional impairment." Developing an understanding of the key differences between voluntary and involuntary action is important because if volitionally impaired defendants are not out-of-control in any literal sense, then a theory for mitigating punishment for action, rather than for the absence of action, is necessary to justify reductions in sentences in these cases.

Professor Morse offers the following illustration, which is quite helpful in appreciating the distinction between voluntary and involuntary action in cases like McBroom:

Suppose you are sitting on a table with your legs dangling over the edge. Assume that you are neurologically intact and that you strongly prefer not to raise your legs. ... [There] are [several] possible ways in which your ... leg might nevertheless move...: (1) Someone strikes your knee in the appropriate place, producing the patellar reflex, and your leg jerks upwards; (2) Someone vastly stronger than you pulls your leg up, despite your valiant resistance efforts; (3) Someone threatens to kill you unless you raise your leg; ... [(4)] An impulse to raise your leg arises and, without thinking, you raise your leg; [(5)] You simply can not understand other-regarding reasons for not doing what you want to do when you want to do it, and you now want to raise your leg, so you do; $[(6)]$... [S]omeone offers you something you want even more than not to raise your leg if only you raise it, so you do.

According to Professor Morse, "The first two cases are uncontroversially cases in which action is lacking: in case one an irresistible neurological mechanism is at work, and in case two an irresistible external force is

${ }^{60}$ See id. at 1590-92 (arguing that there is a "lure of mechanism and metaphor," by which most people wrongly assimilate cases of uncontroversial involuntariness (for example, muscular reflexes, or where an external force physically compels movement) with instances where there is no literal involuntariness).

${ }^{61}$ Id. at $1590-91$. 
literally physically compelling the movement of your body. ${ }^{, 62}$ However, in each of the other cases, he posits that there is "intentional, physically voluntary action."

This may be surprising. Indeed, cases three through six are, to varying degrees, often considered involuntary in common speech: ${ }^{64}$ case three describes a typical duress scenario; case four represents a response to a spontaneous impulse; case five depicts an irrational actor; and case six describes a classic hard choice. But note that none of these cases portray instances of true involuntary action - there is no physical reflexive mechanism or external compulsion at work. With the exception of case five, where one lacks the cognitive ability to appreciate one's own actions, each case involves a rational decision to act voluntarily.

This is the paradigm for voluntary action applied throughout this Comment. In some cases of literal voluntary action, mitigation will be warranted on moral grounds, such as in case five involving the irrational actor. However, in general, criminal law does not excuse or mitigate for intentional and voluntary physical action. ${ }^{65}$ Because the majority of cases where volitional impairment will be claimed actually represent voluntary action, any theory that purports to mitigate punishment must survive close scrutiny.

\section{B. Deconstructing the Major Underlying Theories of Volitional Impairment}

\section{Determinism or the Universal Causation Theory}

The fundamental premise of the theory of determinism, also called universal causation, is that "all human action should (or should not) be morally excused because all acts are nonculpably 'out-of-control' [in some sense]." ${ }^{66}$

Determinism represents a "fundamental psycholegal error" 67 that is made by many under certain circumstances where voluntariness is not immediately apparent. It advocates complete exculpation in every single case of alleged involuntariness, or else in none. Such a proposition creates a dangerous presumption that actors are not ultimately accountable for their

${ }^{62}$ Id. at 1591 .

${ }^{63} \mathrm{Id}$.

${ }^{64}$ See id. ("In all of [the cases], it is undeniably colloquial speech to claim, with varying degrees of success, that one cannot help oneself, that one's act was 'involuntary' ....").

${ }^{65}$ See KADISH \& SCHULHOFER, supra note 18, at 171-81 (discussing culpable conduct and the voluntary act requirement).

${ }^{66}$ Id. at 1592; see also MICHAEL S. MOORE, ACT AND CRIME 156-58 (1993) (discussing the determinist position).

${ }^{67}$ Morse, supra note 27, at 1592. 
conduct. In cases like $M c B r o o m$, describing the defendant's actions as involuntary based on such a theory seems counter-intuitive and wholly unsatisfying. Consequently, determinism has been widely refuted by legal philosophers because

[m]ost human movement is not literally compelled and most acts are not done under unusual constraints that might justify an excuse, such as to avoid threats of death or serious bodily harm or in response to hallucinations. Moreover, if determinism or universal causation were (or were not) true and the basis for an excuse, then everyone would (or would not be) excused for all action, an outcome inconsistent with the arguments for a discrete control excuse. 68

Because determinism essentially reasons that all human action should be excused completely (or, in the alternative, that no action should be excused), it has not been accepted with respect to any affirmative defenses. ${ }^{69}$ To the extent that determinism supports mitigation for out-of-control conduct, it must be rejected for purposes of sentencing as well. The basic arguments used to defeat determinism as a complete defense are entirely applicable in the sentencing context.

First, defendants must be held fully accountable for their own, uncompelled behavior, and only for such behavior. Otherwise, holding people responsible for actions that are externally caused is like leaving the agent out of a story "that talks of [one's own] volitional states as causing those movements."70 We would all be observers, that is, of our own lives, without any accountability for the consequences of our actions. Second, even if determinism were true, punishment and sentencing would still be required in order to ensure just desserts. Even in a determinist universe, injured parties seek retribution for harms they suffer. Thus, determinism or universal causation "does not [require] lack of control in the relevant sense" to support mitigation in cases of alleged volitional impairment. ${ }^{71}$ Reliance on determinism would "require a complete restructuring of our sense of ourselves as responsible agents, our moral practices more generally, and, not least, our system of criminal justice.",72

${ }^{68} \mathrm{Id}$.

69 See id. at 1594 ("Determinism or universal causation does not provide a discrete basis for justifying control excuses."). Indeed, the concept of complete exculpation resulting from the notion that all actions are predetermined is contrary to the very essence of punishment.
${ }^{70}$ MOORE, supra note 66 , at 158.
71 Morse, supra note 27, at 1594.
${ }^{72} \mathrm{Id}$. 


\section{Defect of the Will Theory}

One of the most standard assertions by defendants who allege a lack of self-control is that they suffer some defect of the will. That is, they claim that they lacked a free and operative will at the time of their conduct.

The notion that there is something like volition, or will, inside human beings is perhaps best understood by recalling one's intuitive sense "that 'something' is indeed 'left over' if we subtract the fact that our arm rises from the fact that we raised our arm.", ${ }^{, 73}$ As human beings we have a firstperson awareness of control that we do not have when we are acted upon by forces beyond our control. Thus, there is little dispute that volition somehow exists within the human psyche. Moreover, if an act is voluntary, it must be a product of one's volition. As Alvin Goldman notes: "The primary aim of the theory [of volitions] is to distinguish voluntary from nonvoluntary events." 74

Unfortunately, especially for those asserting a defect of the will as the justification for asserted out-of-control conduct, there is little scientific evidence as to how volition operates. Consequently, the exploration of this topic has largely been left to philosophers as a metaphysical question. ${ }^{75}$ Philosophers have contributed to a more sophisticated understanding of volition by clarifying three key questions: What actions are willed? What is the content of "willing"? How does "willing" cause subsequent action?

\section{a. What Actions Are Willed?}

Justice Holmes took the least complex view regarding willed acts and their scope. To Holmes, "[a]n act is always a voluntary muscular contraction, and nothing else. The chain of physical sequences which an act sets in motion or directs to the plaintiff's harm is no part of it."

73 MOORE, supra note 66, at 134 (paraphrasing LUDWG WITTGENSTEIN, PHILOSOPHCAL INVESTIGATIONS $\S 621$ (3d ed. London 1958)).

74 Alvin I. Goldman, The Volitional Theory Revisited, in ACTION THEORY 67-68 (Myles Brand \& Douglas Watson eds., 1975).

75 Professor Morse has remarked: "The will and free will are not legal criteria, and agents in the criminal justice system would do well to dispense with employing them in responsibility analysis and attribution." Morse, supra note 27, at 1599.

76 OlIVER WENDELL HOLMES, JR., THE COMMON LAW 91 (Boston, Little, Brown \& Co. 1946) (1881). In making this observation, that acts involve only "basic actions," Holmes was actually building on the work of Professor Austin, who had earlier explained:

Most of the names which seem to be names of acts, are names of acts coupled with certain of their consequences. For example: If I kill you with a gun or pistol, I shoot you. And the long train of incidents which are denoted by that brief expression, are considered (or spoken of) as if they constituted an act, perpetrated by me. In truth, 
Contrary to this formulation is the notion that willed acts are not limited to basic actions, but instead encompass a series of circumstances and consequences. ${ }^{77}$ The logical force of this opposing view stems from the observation that in "common speech," an "act" involves more than a simplistic concept of mere muscular contractions. Rather, it extends to the consequences of basic actions as well. ${ }^{78}$ Under this view, it is possible to will yourself "[to] chang[e] a spark plug," for example. ${ }^{79}$ The idea is that this complex act involves willing because, after all, most people do not think in terms of the numerous muscular contractions that are actually involved in changing a spark plug.

This broad understanding of what can be willed, however, has been soundly rejected as too imprecise. ${ }^{80}$ The problem, simply put, is that once circumstances and consequences are included in the same act that is willed, all logical bounds seem to disappear. As one critic has written: "The bodily motions most concisely described [in common speech] as changing a spark plug may also be described as making a living., ${ }^{, 81}$ Thus, it would be too difficult to define what is willed with any specificity. Willed voluntary acts are therefore best understood as simple muscular contractions. Even though, at most, they may be thought of as a series of muscular contractions, they remain basic actions in essence.

Recalling the facts of $\mathrm{McBroom}$, the significance of this conclusion becomes immediately apparent. McBroom's claim was that he lacked the will power to prevent himself from possessing child pornography. Possessing child pornography, however, is not the kind of basic action that can be willed; it is, instead, a complex action that suggests the consequence of a series of basic actions. This description of his action is too broad to be willed.

the only parts of the train which are my act or acts, are the muscular motions by which I raise the weapon, point it at your head or body and pull the trigger.

1 JOHN AUSTIN, LECTURES ON JURISPRUDENCE 290 (Robert Campbell ed., Jersey City, Frederick D. Linn \& Co. 1875).

${ }^{77}$ See Kevin W. Saunders, Voluntary Acts and the Criminal Law: Justifying Culpability Based on the Existence of Volition, 49 U. PITT. L. REV. 443, 449 (1988) (discussing the question of "whether the act-voluntary act distinction is a meaningful one, that is, whether there really is a mental element").

${ }^{78}$ See id. at 450 (discussing the Austin-Holmes theory of muscular contraction and opposing viewpoints). But see AUSTIN, supra note 76, at 290 (refuting the view that an "act" extends to the consequences of "basic actions").

${ }^{79}$ Saunders, supra note 76 , at 451.

${ }^{80}$ See id. at 451 (stating that "the conclusion that an act must include more than bodily movements is not justified, and is not logically sound").

${ }^{81}$ Id. 
A better approach in this case, then, is to focus on the basic actions associated with possessing child pornography. These generally include sitting down in front of the computer, typing on the computer's keyboard, and the individual muscular contractions involved in selecting the pornography from the Internet. These are the kinds of actions that might be subject to a defect of the will, and, obviously, they were performed flawlessly in McBroom's case. McBroom's command over his basic actions was entirely voluntary, reflecting a perfectly functioning will.

\section{b. What Is the Content of "Willing"?}

Professor Austin conceived of willing as a kind of desire or wish; to will something was to desire that it happen. ${ }^{82}$ Other philosophers have similarly argued that people act out of beliefs, desires, or intentions. ${ }^{83}$

Viewed this way, however, the will posed a great mystery. The trouble was that some "operator" was necessary to go from desires, beliefs, and wishes to a bodily movement that successfully satisfied our desires. ${ }^{84}$ Austin attempted to solve this problem by positing a "mental-cause" thesis, whereby action was associated with the will inasmuch as the will was an "action initiator." ${ }^{85}$ Yet, skeptics remained unsatisfied. ${ }^{86}$

Recently, Professor Moore has argued persuasively that the will is best conceived of as a "bare intention." consists of "wants," that is, desires, beliefs, or wishes, because the best reason to believe a human will exists is in the "executory role" that it plays. ${ }^{88}$ According to Moore, wanting or wishing to do something is too compatible

82 See AUSTIN, supra note 76, at 287 ("The desire is commonly called an act of the will; or is supposed to be an effect of a power or faculty of willing, supposed to reside in man.").

${ }^{83}$ See MOORE, supra note 66 , at 117-21 (discussing the approaches of other philosophers).

84 See Morse, supra note 27, at 1595 (stating that the theory of volition seeks to solve the mystery of how intentions and desires lead to voluntary acts). tion).

85 See MOORE, supra note 66, at 113-15 (discussing Austin's thesis on action and voli-

86 It was the inability to explain away this mystery that led Professor Hart to conclude that the law essentially ignores the voluntary act requirement and to dismiss the debate over volition entirely. Hart wrote of his struggle to "find in any legal writings any clear or credible account of what it is for conduct to be voluntary ... in the sense required." H.L.A. Hart, Acts of Will and Responsibility, in THE JUBLEE LECTURES OF THE FACULTY OF LAW, UNIVERSITY OF SHEFFIELD 115, 115-16 (O. Marshall ed., 1960). Hart further claimed that "[volition and the voluntary act] doctrine has only rarely been considered by the courts" and that he was "not convinced that the courts actually do accept [the] general doctrine." H.L.A. Hart, Acts of Will and Responsibility, in FREEDOM AND THE WILL 38, 41 (D. Pears ed., 1963).

87 MOORE, supra note 66 , at $120-21$. "A bare intention is an intention to do a future act"- that is, not an immediate intention. Id. at 119.

${ }^{88}$ Id. 
with not having to do anything to be descriptive of the human will. Thus, he prefers to think of volition as a species of intention:

[Bare intentions] execute our background motivational [e.g., desires] and cognitive [e.g., beliefs] states into actions, ... even when our desires or beliefs are in conflict, [and] account for our failures to execute such beliefs or desires.... Volitions are simply the last executors both of our more general intentions and of the background states of desire and belief that those more general intentions themselves execute.

The significance of Moore's philosophical contribution is great. As long as the content of what is willed was understood to relate to desires or beliefs, a quasi-mens rea had crept into the voluntary act requirement. In other words, without the formation of a desire, which is a mental act, the will was not perceived as able to execute the act. Now that the content of willing can be thought of as a bare intention, however, there is no longer any need to focus on a defendant's mental state for the purpose of understanding whether or not she had an operative will.

Reviewing the McBroom case in light of Professor Moore's contribution is illuminating. When considering the will merely as an executory function, McBroom's wishes, beliefs, and desires are completely irrelevant. In other words, whether or not McBroom actually wanted to stop himself from doing what he did is of no importance to the issue of whether his will was operative. As a result, it is relatively easy to determine that his will was, in fact, perfectly intact, since he was clearly able to execute the basic actions, discussed in the preceding Subpart, which arose from his bare intentions.

\section{c. How Does "Willing" Cause Subsequent Action?}

There has never been substantial scientific evidence supporting the notion that the brain actually causes the body to move. ${ }^{90}$ Until recently, the dearth of scientific evidence was the single most perplexing obstacle to understanding more fully the operation of the human will.

Professor Moore's "executory role" hypothesis contributes to the resolution of this mystery as well. According to Moore, the will is a "functional" or "executory" state, similar to other mental states which translate desires, beliefs, and more general intentions into basic actions. ${ }^{91}$ A func-

${ }^{89}$ Id. at 121.

90 See Saunders, supra note 77 , at $462-64$ (noting that "the mind-body problem may be philosophical and not subject to scientific analysis").

91 See MOORE, supra note 66, at 130-32 (discussing whether volitions are functional states, physical states, behavioral states, or mental states); see also Morse, supra note 27 , at 1596 (explaining Moore's theory). 
tional mental state is a state whose essential nature is specified by the functional roles it plays in causing, and being caused by, other states and events. ${ }^{92}$ The word "pain," for example, names a functional state specified by its role in causing certain behavior, by certain stimuli causing it, and by its relationships with other mental states, such as beliefs and intentions. The will, in Moore's view, involves an executory state along these same lines: "[V]olitions are specified by the role they play in proximately causing bodily motions and in being the effects of both our more general intentions and the belief-desire sets the latter execute." 93

Moore's theory advances our understanding of out-of-control claims based on defects of the will in various ways. In particular, it is now difficult to conceive of a defective will that would render a defendant helplessly lacking in self-control, ${ }^{94}$ even in a highly coercive scenario. Recall, for example, case three from the illustration in Part III.A, ${ }^{95}$ where an individual is placed under extreme duress to act as instructed. Although she is literally compelled to move despite her strong desire not to act under such circumstances, there is no literal defect in her will. Rather, action results because she finds it more difficult to resist the external pressure being imposed than to surrender to the oppressor.

Moreover, one's desires or wishes to remain still have nothing to do with the effectiveness of one's will in such a scenario. ${ }^{96}$ It is apparent that even under such coercive conditions, an individual is able to execute the bare intentions associated with the acts demanded by the oppressor. Even under such pressure, an individual does have a choice to make, and her will is able to execute her decision.

This analysis led Professor Morse to conclude that "the meanings of 'cannot help myself' and 'involuntariness' are not literal, and the alluring metaphor of mechanism [such as a muscular reflex or physical compulsion]

92 See MOORE, supra note 66, at 130 (discussing the role that mental states play in understanding the concept of volition).

93 Id. at 131.

94 Professor Morse points out that, theoretically, there may be one exception to the conclusion that out-of-control agents have intact wills. This would be the case, for example, where there is a duty to act, and the agent wants to fulfill his duty, but is psychologically paralyzed, perhaps due to some phobia. See Morse, supra note 27, at 1596-98 (positing, as an example, a parent with agoraphobia unable to rush outside to help his child who is suffering from a seizure). Morse, however, notes that he has never encountered a judicial opinion involving such a case. See id. at 1597.

95 See supra text accompanying note 61 and accompanying text (noting the example where "[s]omeone threatens to kill you unless you raise your leg").

96 See infra notes 98-121 and accompanying text (rejecting theories, such as the Irresistible Impulse Theory and the Hard Choice Theory, which are often employed to explain the reasons for a claimed absence of volition). 
should not obscure the difference." 97 In other words, in virtually all cases where volitional impairment is claimed, the defective will theories fail, and, therefore, a defendant's will may be considered perfectly operative. Consequently, if mitigation in sentencing is sought, it should be based on something other than the notion that the defendant lacked free will.

\section{Irresistible Impulse Theory}

Defendants who allege they were out-of-control also commonly claim that they had an "irresistible impulse." They argue that they simply could not resist their urges; no matter how hard they tried, they were overcome by their desires to give in.

Impulse control disorders such as kleptomania, pyromania, and pathological gambling are all established categories of mental conditions. ${ }^{98} \mathrm{Al}-$ though not medically identical in nature, compulsive disorders are thought to have a potential for motivational forces similar to impulsive disorders. ${ }^{99}$

However, the fact that such conditions possess a medical diagnosis does not necessarily imply that the actions resulting from impulse disorders are any less voluntary than are "normal" actions. As Professor Morse explains,

[h]uman beings incontrovertibly can be subject to momentary and apparently capricious passions that leave them feeling subjectively unfree and that seem to compromise their ability to control themselves.... [W] hy is [the clinical case of irresistible impulse] different from standard cases of people desiring to fulfill momentary, strong desires? ... After all, why should a powerful desire-really, really wanting something-be assimilated to the patellar reflex? ${ }^{100}$

There simply is no reliable metric with which to determine the magnitude of impulses that would lend credibility to a theory of irresistible impulse. ${ }^{101}$ Moreover, the defendant with an irresistible impulse disorder may

97 Morse, supra note 27, at 1591 (footnote omitted).

98 See id. at 1599 \& n.39 (citing the American Psychiatric Association Diagnostic and Statistical Manual of Mental Disorders, and noting that these disorders may result in behavior for which "the agent will seek an excuse").

${ }^{99}$ See id. at 1600 ("Both impulses and compulsions are often thought to have the potential for coercive motivational force." (citing GEORGE AINSLIE, PICOECONOMICS: THE STRATEGIC INTERACTION OF SUCCESSIVE MOTIVATIONAL STATES WITHIN THE PERSON 205 (1992))).

${ }^{100}$ Morse, supra note 27 , at 1600 . The patellar reflex, of course, is represented by case one, discussed previously. See supra note 61 and accompanying text ("Someone strikes your knee in the appropriate place, producing the patellar reflex, and your leg jerks upwards.").

101 See Morse, supra note 27, at 1657 (noting that even if trained observers could agree that a person exhibits certain impulses, or, by contrast, lacks them, that alone would not necessarily validate that form of observation as a reliable test). 
have even less ground for having her punishment mitigated than would the ordinary, habitually impulsive person. This is because the clinically impulsive defendant "knows that she is especially likely to act thoughtlessly, and may therefore be held accountable for failure to take steps that might remedy habitual impulsiveness or avoid those situations that might facilitate it." 102

Understood this way, affording special treatment to defendants based on irresistible impulse diagnoses allows them to benefit from a character trait that makes correct behavior more difficult for, though obtainable by, them. Professor Morse takes issue with mitigation due to an irresistible impulse along these same lines:

Character rarely furnishes the basis for a legal excuse .... The law assumes that people who are characterologically thoughtless, careless, pugnacious, excitable, cowardly, cruel and the like can be expected to control themselves and should be held accountable if they violate the law. True, it may be harder for such people to behave, but the law assumes that they do not lack the ability to do so.

\section{The Hard Choice Theory}

The most sophisticated theory regularly employed by defendants claiming a lack of self-control posits that control over one's conduct resides in the ability to choose. Recall, for example, case six from the illustration in Part III.A. ${ }^{104}$

The basic claim involves two parts. First, the mental abnormality is presumed to coerce the defendant internally to act wrongfully. Second, the defendant is portrayed as facing an excruciatingly hard choice. ${ }^{105}$ Essentially, the hard choice theory states that: "[Y] ou want to do something that you know you should not do, but you feel like you must do it anyhow because the pain of not doing it will be unbearable."106

${ }^{102}$ Id. at 1601.

103 Id. at 1602. Professor Morse acknowledges that it is sometimes hard to conform one's behavior, but he also thinks that it can be difficult for everyone at varying moments in one's life. In an effort to explain why it is difficult for humans to keep "flying straight," as he puts it, Morse suggests a list of several "self-control strategies" that are helpful to anyone who is struggling to remain in control. His list is not intended to be exhaustive, and includes the following: self-consciousness (the ability to monitor oneself), fear of consequences, moderate temperament, and the capacity for empathy or identification with others. See id. at 1605-10.

104 See supra text accompanying note 61 ("Someone offers you something you want even more than not to raise your leg if only you raise it, so you do.").

${ }_{105}$ See Morse, supra note 27, at 1611-34 (discussing lack of control as "hard choice").

$106 \mathrm{Id}$. at 1619. Professor Morse notes that the intended analogy in hard choice cases is to situations of extemal duress. The idea is that the internal pain acts like an external force deserving of special consideration. Morse rejects the analogy in most cases, arguing that any 
In hard choice cases, the defendant experiences intense and unpleasant emotions that can only be alleviated through wrongful action. As Professor Morse explains: "Although some ... 'positive' experience of 'release' will accompany the wrongdoing, the primary motivation is the avoidance of dysphoria."107 It was this scenario that ultimately convinced the Third Circuit in McBroom that the defendant's actions deserved reduced punishment. The court reasoned, for example, that McBroom's condition was "a phenomenon which is not about erotic gratification, but about an attempt to control the overwhelming mental pain and tension that may accompany an unfulfilled compulsion." 108 This model seems to support a common sense notion of uncontrollable behavior. Yet, upon closer scrutiny, it too fails to persuade that the individual is literally out-of-control.

Hard choice scenarios are more difficult to analyze because, as the term suggests, the defendant in fact faces an unusually difficult decision. The problem, however, is that "those wishing to draw an analogy to examples of no literal choice" equate a hard choice with no choice. ${ }^{109}$ Indeed, hard choice situations do not involve classic uncontroversial involuntariness, because they are not physical compulsions or reflexive responses. In addition, defendants in hard choice scenarios act intentionally and exercise free choice when they decide to avoid dysphoria by acting wrongfully. Furthermore, in choosing to avoid dysphoria, defendants make perfectly sensible choices. ${ }^{110}$

Recalling the facts in McBroom highlights the complex dynamics of hard choice scenarios. McBroom contended that his actions were in response to a painful compulsion. Yet, objectively speaking, he was never physically forced to sit at his computer and download contraband material; nor was his conduct a response to any muscular reflex. In fact, rather than resisting his intense craving, $\mathrm{McBroom}$ knowingly elected to succumb to a legally and morally reproachable option. Although this may have been perfectly rational under the circumstances, the key concept to grasp is that his resulting action was the product of his own free and voluntary decision-

mitigating effect must be based on some criteria other than involuntariness. See id. at 161134.

${ }^{107}$ Id. at 1619-20. The lay definition of dysphoria is "a generalized state of feeling unwell or unhappy." WEBSTER'S THIRD NEW INTERNATIONAL DICTIONARY 712 (1981).

108 United States v. McBroom, 124 F.3d 533, $541-42$ (3d Cir. 1997); see also id. at 540 (accepting testimony that "if the phrase 'significantly reduced mental state' is intended to include a reduced capacity for choice . . . then Mr. McBroom's condition . . . fulfills that definition").

${ }^{109}$ Morse, supra note 27, at 1604.

110 See id. at 1622-24 (discussing the mental processes in which internally coerced agents engage in order to avoid dysphoria). 
making. His choice may have been hard, but he did have one. Consequently, he should be held accountable for it.

This literalist proposition is typically countered by one facet of hard choice scenarios that has not been mentioned. Namely, some argue that even if, technically speaking, a rational choice has been made, the quality of the choice is not meaningful. In other words, in the defendant's mind, at least, there is no real choice. ${ }^{111}$ Indeed, some hard choice scenarios will warrant reduced punishment because as a society we deem the quality of the choice faced to be simply too hard. ${ }^{12}$ But it is important to emphasize that in such cases we are not mitigating under the assumption that the defendant has had no choice. Furthermore, such situations in which we are asked to mitigate out of mercy for the difficulty of the choice confronted by the defendant raises serious problems of line-drawing. ${ }^{113}$

Whether or not a defendant is deemed to have had a choice is important for two key reasons. First, if a defendant's motive for satisfying a desire is not the avoidance of dysphoria, but purely for pleasure, then there is no compulsion to worry about, no matter how strong the desire. ${ }^{114}$ However, to automatically assume that there was no choice in these cases would mitigate punishment unnecessarily. Second, even if a defendant was motivated by the desire to avoid pain, if the goal of the compulsive behavior is senseless, such as when a kleptomaniac steals a car for no reason at all, then craving for it may collapse into a rationality problem. ${ }^{115}$ As will be discussed in Part IV.B, irrationality offers useful alternative grounds for mitigation because it avoids the misperceptions surrounding out-of-control theories.

Note that defendants in hard choice scenarios cannot credibly point to any defect of the will. The human will, now properly understood, ${ }^{116}$ is an executory mental state whose role is simply to translate bare intentions into basic actions; it does not interfere with voluntariness in any way. Moreover, even if a defendant were irrational, the executory function of the will would

111 See id. at 1614 (discussing a basic working model for such coercion excuses, i.e. "[e]ven though the person has a choice among actions-that is, no superior force is physically moving her body - there is no 'real' or 'acceptable' alternative").

${ }^{112}$ See infra notes 144-55 and accompanying text (discussing judges' departures from the sentencing guidelines based on section $5 \mathrm{~K} 2.13$, and in light of varying concerns about the defendants' plights).

113 Deciding the point at which a hard choice becomes too difficult and deserves mercy is a highly subjective endeavor.

114 See Morse, supra note 27, at 1624 (noting that "seeking pleasure is surely a rational reason to form an intention").

115 See id. at 1624 ("If a person's ultimate goal ... is properly characterized as irrational, craving for it collapses into a rationality problem ....").

116 See supra Part III.B.2 (deconstructing the theory of a defect of the will). 
still perform effectively, producing action that satisfies her intense, though irrational, bare intentions. ${ }^{117}$

Nor can defendants facing a hard choice scenario argue that their punishment should be mitigated under a determinist view of the world, ${ }^{18}$ or in light of the irresistibility of their impulses. ${ }^{119}$ Just as there is no reliable evidence that "abnormal" desires are necessarily stronger than are "normal" desires, there is no reason to believe that the hard choices these desires present are any more difficult for some than for others. ${ }^{120}$

Taken together, these points combine to refute the notion that hard choices represent no choices and, by implication, that a defendant acts involuntarily under such circumstances. In fact, in such scenarios the defendant does have self-control, and makes a free (though admittedly difficult) choice. But, as Professor Morse has aptly concluded,

[t]here is good reason to believe... [that in most hard choice cases] the choice is probably not so hard that one could not fly straight rather than commit serious crimes.... [Mitigating punishment] in such cases would be a morally perverse result based on a behavior assessment technology that we lack. ${ }^{121}$

\section{Summary}

The main conclusion to be drawn from the foregoing discussion is that the label "volitional impairment" is misleading. The goal of defendants who invoke it is to draw upon a metaphorical connection to select cases of uncontroversial involuntariness, such as muscular reflexes and instances of external physical compulsion. This practice is alarmingly successful: many voluntary acts often appear to be involuntary to the casual observer. Examples include action compelled under duress, so-called irresistible impulses, hard choices, and cases involving irrational behavior. However, once the underlying theories that attempt to link such situations with involuntariness are deconstructed and scrutinized, it becomes clear that volitional impairment should not be associated with a lack of self-control in a literal sense for any of these cases.

117 See Morse, supra note 27, at 1625 ("[T] a person has intense, irrational desires that cause great dysphoria.").

${ }^{118}$ See supra Part III.B.1 (explaining that for the determinist view to be logically consistent, no humans should ever be held to be culpable).

119 See supra Part III.B.3 (deconstructing the irresistible impulse theory, which is often asserted by defendants who claim that they cannot resist their urges).

${ }^{120}$ See supra note 101 and accompanying text (arguing that there is no reliable way to measure irresistible impulses).

121 Morse, supra note 27, at 1633-34 (footnote omitted). 
Each of the major theories underpinning claims about the effects of volitional impairment on a defendant's mental capacity and on her ability to engage in actions voluntarily prove unsatisfactory. The proposition that human beings are subject to determinism or universal causation, whereby all actions are predetermined, is easily refutable. The concept of a defective human will is nonsensical once the will is understood to represent an executory mental state. There is simply no evidence to support the notion that abnormal impulses are more irresistible than normal ones just because a defendant has been diagnosed with an impulse disorder. Finally, the notion of hard choice should not be analogized to situations involving no choice. Thus, as a general matter, so-called "out-of-control" defendants seem able to choose between alternatives, to exercise free will, and to act voluntarily.

\section{VOLITIONAL IMPAIRMENT AND SENTENCING IN THE FEDERAL COURTS}

With the meaning of volitional impairment clarified, it remains to be established precisely why this concept should not serve as a basis for reduced mental capacity departures under Guidelines section $5 \mathrm{~K} 2.13$. There are three main arguments against its use. The first is an extension of the principles already set forth in Part III: sentencing departures are not warranted for most defendants who claim to be out-of-control, because in the vast majority of cases their condition does not imply a literal lack of selfcontrol, making them morally responsible for their actions. ${ }^{122}$ Second, it is appropriate and necessary to refuse to mitigate punishment in such cases in order to ensure that Congress's primary objectives in enacting the Guidelines are satisfied. Third, given the widespread misperceptions regarding the meaning of volitional impairment, section $5 \mathrm{~K} 2.13$ can become a dangerous tool in the hands of sentencing courts, potentially subject to abuse.

In light of these practical concerns about implementing a standard that allows for departures based on volitional impairment, a better approach relies on more traditional and well-established grounds for asserting reduced mental capacity, namely, cognitive impairment. ${ }^{123}$ As Professor Morse has

122 Note that in cases involving true involuntary action (for example, muscular reflexes and physical compulsion), the law provides the defendant a complete defense because the voluntary act element of the crime is not satisfied. See KADISH \& SCHULHOFER, supra note 18, at 175-78, 994-98 (discussing involuntary action generally). Similarly, the defendant who is able to establish irrationality is also completely excused by virtue of an insanity defense. See $i d$. at 929-32 (discussing the insanity defense generally). Such defendants have no need for sentencing departures.

${ }^{123}$ Recall the gist of the M'Naghten test for cognitive ability: whether the defendant did not know the "nature and quality of the act he was doing; or if he did know it, that he did not know he was doing what was wrong." Daniel M'Naghten's Case, 8 Eng. Rep. 718, 722 (H.L. 1843); see also supra notes $17-18$ and accompanying text. 
concluded, "[m]any of the cases we mistakenly or loosely term 'volitional' or involuntary" are actually problems of rationality. ${ }^{124}$

Unfortunately the Commission has adopted $\mathrm{McBroom}$ wholesale, apparently oblivious to the inherent deficiencies of such a decision. Once again, it seems it will be up to Congress to address volitional impairment and to avoid its potentially deleterious consequences in the sentencing context. $^{125}$

\section{A. Rejecting Volitional Impairment as Grounds for Section $5 K 2.13$ Departures}

\section{Voluntary Actions and Moral Responsibility}

It has been argued up to this point that, despite widespread misperceptions to the contrary, volitionally impaired defendants do not literally act involuntarily. Even this proposition is understood and accepted, some may still feel the need to either excuse or mitigate punishment for allegedly outof-control defendants on moral grounds. Their concern is that even if the action was voluntary, the impulse was simply too strong, or the choice too difficult, to morally justify unmitigated punishment.

Until recently, classic theories of moral responsibility relied primarily on the concepts of voluntariness ${ }^{126}$ and choice ${ }^{127}$ for ascribing moral blame. These theories may, in fact, support mitigation for an allegedly volitionally impaired defendant like McBroom even though his actions are properly understood as voluntary. This is because an argument could be made that the choice he faced was not meaningful, or his impulse too strong, or any other explanation that might justify involuntariness. However, these theories of moral responsibility have largely been discredited in recent years because

124 Morse, supra note 27, at 1624.

125 Recall that Congress ultimately resisted any role for volitional impairment during the guilt phase of federal trials, thereby deciding an issue that had previously been unsettled. See supra Part I. The new amendments to the Sentencing Guidelines are valid as proposed by the Sentencing Commission unless modified or rejected by Congress. See U.S. Sentencing Commission, Amendments to the Sentencing Guidelines (May 18, 1998), available in U.S. Sentencing Commission Homepage (visited Feb. 17, 1999) $<$ http://www.ussc.gov/pdf/98amend2.htm> (noting on its coverpage that the official text of the amendments were submitted to Congress for review and ratification).

${ }^{126}$ See Aristotle, Nicomachean Ethics, Book III, in THE SPECTRUM OF RESPONSIBIITY 24-33 (Peter A. French ed. \& David Ross trans., 1991) (representing the classic view of responsibility that people are accountable for their voluntary acts).

127 See Harry G. Frankfurt, Alternate Possibilities and Moral Responsibility, in THE SPECTRUM OF RESPONSIBIITY, supra note 126, at 102-11 (arguing that an agent is morally responsible for what she has done only if she could have done otherwise). 
they are an incomplete guide to understanding moral blameworthiness. ${ }^{128}$ An alternative theory is required, then, if we are to appreciate the relationship between moral blameworthiness and punishment in cases such as McBroom.

Professor R. Jay Wallace has provided such a theory. ${ }^{129} \mathrm{He}$ argues that "[b]eing a responsible moral agent ... is not really a matter of [voluntariness or] freedom of the will. Rather, it primarily involves a form of normative competence: the ability to grasp and apply moral reasons, and to govern one's behavior by the light of such reasons." 130 The "moral reasons" Wallace refers to are the reactive emotions-"resentment, indignation, and guilt." ${ }^{\text {"131 }}$ His conception of moral responsibility is important because it implies that most defendants who are able to reason and reflect upon what they do are responsible for their actions. In essence, the lack of having any ability to perform self-reflection, not the involuntariness of one's actions, is what excuses an agent from moral blame. ${ }^{132}$

Professor Wallace makes several key observations that help to explain the proper role of sentencing in terms of moral responsibility. First, to hold a defendant morally responsible is nothing more than to hold her to certain expectations which society has set for itself and accepted. The question, thus, is a normative one- that is from the standpoint of the moral judge, not the judged. ${ }^{133}$ In other words, it is generally not important what the defendant thought or felt about the morally reprehensible conduct; the critical issue is how society feels about it.

128 The main problem with relying on voluntary actions, of course, is that voluntariness is to a large extent a metaphysical question. See supra note 75 and accompanying text (noting that the lack of scientific evidence on the operation of volition means that the topic is a metaphysical question for philosophers to discuss). Many cases in which action is deemed involuntary actually involve a judgment call by the court. See Frankfurt, supra note 127, at 108. As Harry Frankfurt notes, "We often do ... excuse people for what they have done when they tell us (and we believe them) that they could not have done otherwise. But this is because we assume that what they tell us serves to explain why they did what they did." Id. at 110 .

129 See R. JAY WALlaCE, RESPONSBBITIY AND THE MORAL SENTIMENTS 1 (1994) ("This is a book about moral responsibility. In the most basic terms, it sets out to provide an account of the kind of moral agency in virtue of which people are morally responsible for the things they do.").
${ }^{130}$ Id.
131 Id. at 62.

132 See id. at 183 ("[W] hat matters is not the ability to exercise ... reflective self control, but simply the possession of such powers ....").

${ }^{133}$ See id. at 5 ("I propose that we interpret the debate about moral responsibility in normative terms.... [W] cannot establish what it is to be a morally responsible agent unless we first understand the stance of holding someone responsible-the stance of the moral judge, rather than of the agent who is judged."); see also id. at 62-74 (discussing responsibility and the reactive emotions, generally). 
Second, although the practice of holding defendants responsible may be consistent with retributivist notions of justice, it is incorrect to assume that this is necessarily wedded to moral responsibility in any pejorative sense. Holding people responsible need not be linked to attitudes of vengeance or cruelty. Rather, the emotions expressed by sanctioning are "focused emotional responses to the violation of moral obligations that we [as a society] accept." 134 To hold a defendant responsible is not to condemn her for who she is, it is only to punish her for what she did, in order to ensure that the moral values of society in general are protected.

Finally, and most importantly, the fact that a defendant may face a hard choice makes little difference to Wallace's view of moral responsibility, as long as the defendant's ability to reflect is present. The ability to reason, or cognitive ability, is the key. Impulses, for example, no matter how strong, are thought to have no impact on the defendant's ability to reason effectively about what she does. ${ }^{135}$ Regardless of the quality of the choice, Wallace concludes that as long as the defendant is left with the ability to turn choice into action, then even if it would take "Odysseus-like" efforts to resist the impulse, "it would seem reasonable to treat $\mathrm{h}[\mathrm{er}]$ as morally accountable."136

Therefore, where a defendant is aware of her actions and can appreciate the implications of her behavior, it is both appropriate and necessary to ascribe full, unmitigated moral and legal responsibility to her. The failure to do so is the equivalent of cheating society by not enforcing the agreed upon moral standards uniformly. Absent any rationality defects in the defendant, reducing punishment based on volitional impairment amounts to nothing more than mitigating sentences for knowing and voluntary behavior. This is not only unfair to those convicted of the same offense, and to those who will not stand to benefit from section $5 \mathrm{~K} 2.13$, but it is also morally irresponsible.

\section{The Federal Sentencing Objectives}

Mitigation is appropriate when special circumstances or limitations are insufficient to justify or excuse conduct, but do indicate that the defendant encountered unusual difficulty in conforming to the requirements of the law. ${ }^{137}$ The Guidelines adopt this general principle, and section 5K2.13

134 Id. at 69.

135 See id. at 170-80 (positing various situations where an individual may, or may not be, morally accountable depending on the capacity to engage in "reflective self-control").

136 Id. at 173-74.

137 See generally C.T. SISTARE, RESPONSIBLITY AND CRIMINAL LIABILITY 32 (1989) ("The agent who makes a successful claim of excuse[,] ... justification, or mitigation is exempted from the normal course of legal response."). 
specifically was designed to provide leniency in sentencing for federal offenders who suffer from reduced mental capacities. ${ }^{138}$ However, in order to assess whether considering volitional impairment as an alternative standard for reduced mental capacity is proper, we must reflect carefully upon Congress's primary objectives in promulgating the SRA.

Recall that Congress intended for its new sentencing structure to address all of the basic purposes of criminal punishment: deterrence, incapacitation, just punishment, and rehabilitation. ${ }^{139}$ Additionally, an overarching goal of Congress's reform efforts was to reduce nationwide disparities in sentencing. ${ }^{140}$

In light of these considerations, it is clear that even if volitional impairment was equivalent to involuntary action, which it is not, then departures based on such grounds would fail to advance Congress's objectives. For example, volitional impairment might point to a lighter sentence under the principle of just punishment, because the conduct could "not be helped." "141 But this would simultaneously justify a heavier sentence under other, equally important principles. In particular, the need for incapacitation would be arguably much greater for volitionally impaired offenders because their conduct would be uncontrollable and would pose a serious threat to society. These other principles of criminal punishment emphasized by Congress must not be slighted. ${ }^{142}$

Moreover, because volitional impairment does not literally represent involuntary action, allowing it to serve as a basis for departures would severely frustrate the important objective of reducing nationwide disparities in sentencing. Congress attempted to tackle this problem by mandating a more structured sentencing regime, whereby similarly situated defendants would receive similar punishments. ${ }^{143}$ But by allowing sentencing courts discretion to depart from the Guidelines based on volitional impairment, a concept whose true significance is widely misunderstood, judges will undoubtedly mitigate punishment in cases where the conduct does not deserve leniency. Two defendants committing the same offense will be subjected to disparate treatment simply because one has been able to convince the sentencing

138 See supra note 40 and accompanying text (noting that leniency is an appropriate consideration under the Guidelines in certain situations).

139 See supra note 35 and accompanying text.

140 See supra note 36 and accompanying text.

141 This is how the "lure of mechanism and metaphor" is commonly expressed. See supra note 60 and accompanying text.

142 See United States v. Pullen, 89 F.3d 368, 371 (7th Cir. 1996) (discussing the importance of considering all of Congress's and the Commission's sentencing objectives).

${ }^{143}$ See supra note 36 and accompanying text (indicating that one of Congress's broad goals was to avoid sentencing disparities). 
judge that her volitional impairment somehow "compelled" her to act, while the other is unable to substantiate such a claim. This is a scenario remarkably like the indeterminate system that Congress expressly hoped to eliminate through sentencing reform.

Consider how several post-McBroom decisions have struggled with the notion of volitional impairment in the sentencing context. United States $v$. Carucci is a recent case in which the court addressed volitional impairment pursuant to newly revised section $5 \mathrm{~K} 2.13 .{ }^{144}$ Carucci, formerly a floor broker on the New York Stock Exchange, pleaded guilty to engaging knowingly in unlawful securities trading over a period of more than four years. ${ }^{145}$ Prior to sentencing, Carucci moved for a downward departure pursuant to section $5 \mathrm{~K} 2.13$, claiming that "he committed his crimes while suffering from a significantly diminished mental capacity attributable to a compulsive gambling disorder."146 Although the court acknowledged the medical compulsion, and despite the fact that Carucci testified that he suffered from the same "psychotic demons," at work as he did in other aspects of his life, the court refused to grant the departure. The court made the distinction that "a compulsive gambler is not a fortiori, a compulsive illegal trader."147

In United States $v$. Stevens, the defendant was charged with one count of possession of child pornography, in a case factually very similar to McBroom. ${ }^{148}$ Despite the fact that a medical expert testified that the defendant was "compulsive in his on-line forays," the court refused to depart pursuant to section $5 \mathrm{~K} 2.13$. $^{149}$ Among other factors, the court looked to the defendant's apparent ability to have a "very full leisure life," as justification for its conclusion that he was not volitionally impaired. ${ }^{150}$ Interestingly, the Third Circuit was not persuaded by this very rationale in McBroom, ultimately dismissing McBroom's outwardly normal and productive life, and finding him volitionally impaired nonetheless. ${ }^{151}$

Finally, in United States $v$. Bennett, the defendant pled nolo contendere to various charges of fraud. ${ }^{152}$ Based on his belief that he was on a God-

1441999 U.S. Dist. LEXIS 292 (S.D.N.Y. Jan. 14, 1999).

145 See id. at * 1 .

${ }^{146}$ Id.

147 Id. at $* 3$.

14829 F. Supp. 2d 592 (D. Alaska. 1998).

149 Id. at 609.

150 Id: see also infra notes 197-201 and accompanying text.

151 United States v. McBroom, 124 F.3d 533, 550 (3d Cir. 1997) ("We note ... that an individual's average or above-average mental capacity in one aspect of his or her affairs is not necessarily relevant to a determination about the individual's mental capacity in another aspect.").

152 F. Supp. 2d 513, 516 (E.D. Pa. 1998). 
ordained mission, the defendant devised, developed, and managed what became an extremely large financial enterprise that ultimately owed in excess of $\$ 100$ million to its unfortunate "investors." 153 Because of inconclusive medical testimony concerning the medical competency of the defendant, the sentencing judge was left with little guidance. Ultimately, in light of the judge's overall sense from the evidence, and pursuant to the authority vested by $\mathrm{MCBroom}$, the judge granted a departure without definitive proof that the defendant was volitionally impaired. ${ }^{154}$

These cases illustrate the crucial problem that exists with the standard proposed by $M c B r o o m$, and now adopted by the Sentencing Commission: there is a complete lack of a reliable metric for assessing volitional impairment. That fact causes equal concern, whether it is being used as part of a test for an affirmative insanity defense, or whether it is part of a standard for determining reduced mental capacity in sentencing. The Carucci court easily could have justified a departure on the ground that the compulsive disorder affected the defendant's role as a trader; it simply chose not to do so. The Stevens court, similarly, could have justified a departure. Finally, the Bennett court perfectly illustrated how baffling such decisions can be without clear guidance.

Indeed, research suggests that all too often "departure is driven by the sentencing judge's desire to reach a result different from that specified in the Guidelines, rather than by the presence of meaningfully atypical facts." 155 Accordingly, the suggestion has been made that "[ $t]$ he Commission [should] improve its efforts to articulate clear and sensible policies underlying Guidelines provisions; these efforts are necessary to build consensus and provide clearer guidance to both district and appellate judges regarding the situations in which departure is appropriate."156

${ }^{153}$ See id. at 517-18.

154 See id. at 527 ("Regardless on one's point of view, defendant's cognitive faculties or volition, or both, appear to have been subject to some form of extraordinary distortion and, perhaps, significantly reduced capacity." (emphasis added)).

${ }^{155}$ Michael S. Gelacak et al., Departures Under the Federal Sentencing Guidelines: An Empirical and Jurisprudential Analysis, 81 MNN. L. REV. 299, 364 (1996); cf. United States v. Goossens, 84 F.3d 697, 704 (4th Cir. 1996) (suggesting that a downward departure under section $5 \mathrm{~K} 2.13$ could depend on the defendant's "substantial assistance" to police); United States v. Cantu, 12 F.3d 1506, 1509 (9th Cir. 1993) (granting a downward departure under section $5 \mathrm{~K} 2.13$ to a Vietnam War hero).

156 Gelacak et al., supra note 155 , at 365 . The need for clear and sensible policies is amplified by the fact that sentencing courts have discretionary authority to depart from the Guidelines sua sponte. See Selya \& Kipp, supra note 33, at 12 (explaining that Congress created a system of limited appeals of sentences in federal courts to "safeguard $\square$ the residual discretion of the sentencing judge"). 
The Third Circuit's intentions may have been well founded when it boldly decided McBroom. ${ }^{157}$ Yet, in so doing, it inadvertently opened the door to fairly broad sentencing discretion, at least in the area of diminished capacity departures. Between the authority vested in sentencing judges by Koon v. United States, to consider the merits of all departures, and the power now granted by the Commission to depart based on the oftmisunderstood concept of volitional impairment, the remnants of indeterminate sentencing are beginning to reappear. Although sentencing judges may cherish this relatively unfettered degree of discretion in the area of section $5 \mathrm{~K} 2.13$, it stands to seriously undermine Congress's goal of reducing sentencing disparities, one of its main objectives in enacting the SRA.

\section{Volitional Impairment and the Potential for Abuse}

In McBroom, the Third Circuit considered the most obvious concern about allowing section $5 \mathrm{~K} 2.13$ departures based on volitional impairment, namely the possibility of reduced sentences for any defendant who " felt compelled' to commit a crime."158 The court reasoned that its decision would not open any floodgates because there were numerous limitations already imposed on section $5 \mathrm{~K} 2.13$ departures. The court explained:

[S]ection $5 \mathrm{~K} 2.13$ requires that the reduced mental capacity be "significant" before a downward departure may be considered. Likewise, a departure, if granted, should reflect the extent to which the offender's reduced mental capacity contributed to the commission of the offense.... [A] departure may not be granted where the offense is not "non-violent," and a departure is not warranted when the defendant's criminal history indicates a need for incarceration to protect the public. In addition, the reduction in mental capacity may not be the result of the offender's voluntary use of drugs or other intoxicants. Taken together, the requirements of section $5 \mathrm{~K} 2.13$ are not easily met. In addition, the district courts retain their discretion to deny a downward departure ....

Presumably, the Commission wholly endorses the Third Circuit's view that these protections are sufficient. However, these heavily relied upon restrictions may not, in fact, be as stringent as they first appear. Consider the requirement that an offense be "nonviolent" before a defendant may be eli-

157 The Third Circuit arguably exceeded the scope of its authority; by allowing volitional impairment to serve as a valid criteria for section $5 \mathrm{~K} 2.13$ departures, the court performed a quasi-legislative function and encroached on the Commission's area of expertise. See Herten, supra note 29, at 666 (echoing this point, and noting that "when a question arises as to whether the guidelines take into consideration a given factor, the proper authority to consult is the Sentencing Commission, not the individual judges").

158 United States v. McBroom, 124 F.3d 533, 549 (3d Cir. 1997).

159 Id. at 548 (citations omitted); see also U.S. SENTENCING GUIDELINES MANUAL. $\S 5$ K2.13 (Policy Statement) (1997). 
gible for a section $5 \mathrm{~K} 2.13$ departure. ${ }^{160}$ Several circuits have defined the term "nonviolent offense" as any crime that does not have "as an element the use, attempted use, or threatened use of physical force."161 This standard tends to create a bright-line distinction between violent and nonviolent offenses. ${ }^{162}$ By contrast, other circuits have applied a more fact-specific inquiry to determine whether the underlying conduct was, indeed, nonviolent. ${ }^{163}$

The recent amendments to section $5 \mathrm{~K} 2.13^{164}$ essentially represent a compromise approach to the circuit conflict over nonviolent offenses. The new section $5 \mathrm{~K} 2.13$ allows a diminished capacity departure in most cases; it states, in relevant part, that a departure is not allowed where "the facts and circumstances of the defendant's offense indicate a need to protect the public because the offense involved actual violence or a serious threat of violence." 165

Note that even under the newly revised section $5 \mathrm{~K} 2.13$, whether the offense disqualifies a defendant from the possibility of departure is still a fact-

${ }^{160}$ See generally Seth A. Travis, Comment, Guiding the Sentencing Court's Discretion: A Proposed Definition of the Phrase "Non-Violent Offense" Under United States Sentencing Guideline $\S 5 K 2.13,86$ J. CRIM. L. \& CRIMINOLOGY 530 (1996) (discussing a circuit split on the definition of "non-violent offense" under section 5K2.13). This was certainly an issue prior to the Sentencing Commission's recent amendments to section $5 \mathrm{~K} 2.13$, and it is yet to be seen whether or not the issue has been fully resolved.

${ }^{161}$ Id. at $531 \&$ n.8. These circuits interpret the phrase "non-violent offense" in section $5 \mathrm{~K} 2.13$ to be the contrapositive of the term "crime of violence" under Guidelines section 4B1. See id. at $531 \& \mathrm{nn} .9-10$. Under this view, any crimes defined as violent under section 4B1.2 are not "non-violent offenses."

162 See, e.g., United States v. Poff, 926 F.2d 588, 589-91 (7th Cir. 1991) (denying a departure for the "violent" crime of writing threatening letters to the President of the United States, despite the fact that the defendant never intended to carry out her threats); United States v. Russell, 917 F.2d 512, 517 (11th Cir. 1990) (holding that the definition of "nonviolent offense" under section SK2.13 is the contrapositive of "crime of violence" in section 4B1.2) (citing United States v. Gonzales-Lopez, 911 F.2d 542, 548 (11th Cir. 1990)); United States v. Rosen, 896 F.2d 789, 791 (3d Cir. 1990) (same); United States v. Maddalena, 893 F.2d 815, 819 (6th Cir. 1989) (same).

${ }^{163}$ See, e.g., United States v. Weddle, 30 F.3d 532, 540-41 (4th Cir. 1994) (affirming a sentencing court's downward departure where the defendant mailed threatening communications to his wife's lover and tried to run him off the road); United States v. Chatman, 986 F.2d 1446,1447 (D.C. Cir. 1993) (vacating a sentencing court's refusal to depart downward where the defendant had committed an unarmed bank robbery); see also United States v. Philibert, 947 F.2d 1467, 1471-72 (11th Cir. 1991) (determining whether an offense was nonviolent pursuant to section $5 \mathrm{~K} 2.13$ without examining the definition found in section 4B1.2), implied overruling recognized by United States v. Bonner, 85 F.3d 522, 527 (11th Cir. 1996) (holding that the threatened use of force is a violent crime and thus not grounds for downward departure); United States v. Spedalieri, 910 F.2d 707, 711 (10th Cir. 1990) (same).

164 See supra notes 49-52 and accompanying text (discussing the Guidelines and its recent amendments).

165 See supra note 49 and accompanying text. 
specific inquiry. Accordingly, the list of volitionally impaired offenders potentially entitled to departure may be very surprising. Bank robbers, ${ }^{166}$ stalkers, ${ }^{167}$ drug dealers, ${ }^{168}$ felons in possession of firearms, ${ }^{169}$ bank defrauders, ${ }^{170}$ and others convicted of federal offenses ${ }^{171}$ might be eligible for reduced sentences if, on the particular facts and circumstances of each case, the sentencing court decides that the charged crime is not actually violent and does not involve a serious threat of violence.

This broad standard for characterizing the violent nature of the offense will not only open the door to reductions in sentences in numerous cases where mitigation is unwarranted, but it is likely also to create an increased burden on the criminal justice system, with more defendants demanding section 5K2.13 departures. Contrary to the Third Circuit's intuition, therefore, there is ample evidence that the floodgates will, indeed, be opened to some extent now that volitional impairment has been added as a relevant consideration under section $5 \mathrm{~K} 2.13$.

Moreover, a recent empirical analysis of the Guidelines' departure practices across the country indicates that "departure practices [do] ... mirror applicable appellate jurisprudence." ${ }^{.172}$ Thus, because the Commission now endorses volitional impairment as a factor in section $5 \mathrm{~K} 2.13$ departures, it is essentially increasing the number of departures granted by sentencing courts on such grounds. This is especially alarming in light of the widespread misperceptions regarding the meaning of voli-

166 See, e.g., Chatman, 986 F.2d at 1448-54 (establishing that a bank robbery was nonviolent because the defendant was unarmed and had a significantly reduced mental capacity).

${ }^{167}$ See, e.g., Weddle, 30 F.3d at 537-40 (establishing that stalking was nonviolent because the defendant was unarmed and had a significantly reduced mental capacity); see also Poff, 926 F.2d at 589-93 (suggesting another possible nonviolent crime under a fact-specific inquiry).

See, e.g., United States v. Withers, 100 F.3d 1142, 1148 (4th Cir. 1992) (describing a scenario whereby the court refused to depart downward for a defendant convicted of drug dealing, not because the crime was violent, which is ordinarily a threshold question, but because the defendant was "able to absorb information in the usual way"); United States v. Hamilton, 949 F.2d 190, 193 (6th Cir. 1991) (same).

169 See, e.g., United States v. Cantu, 12 F.3d 1506, 1513-14 (9th Cir. 1993) (suggesting that felony possession of firearms may be nonviolent under a fact-specific inquiry).

${ }_{170}$ See, e.g., United States v. Johnson, 979 F.2d 396, 397 (6th Cir. 1992) (allowing a downward departure in a case involving high-level bank fraud).

171 See e.g. United States v. Ruff, 948 F. Supp. 1351, 1359 (M.D. Ala. 1998) (noting that although the defendant pled guilty to breaking into a United States post office, he is "eligible" to receive a departure under section $5 \mathrm{~K} 2.13$ ).

172 Gelacak et al., supra note 155 , at 359. 
tional impairment, ${ }^{173}$ an unfortunate reality that exponentially increases the possibility for greater disparities in sentencing.

The Third Circuit itself recognized the potential for abuse stemming from its decision to expand opportunities for departures under section 5K2.13. ${ }^{174}$ Unfortunately, it overestimated the limiting effect of many of the restrictions contained within that section of the Guidelines. It should be clear by now that at least some of these perceived restrictions may actually be loosened to allow federal offenders access to departures in some surprising cases, depending upon the sentencing court's interpretation of the facts. ${ }^{175}$ Affording sentencing courts the luxury of exercising even more discretion, based on a generally unclear understanding of volitional impairment, only invites more uncertainty and ambiguity than can possibly be good for the system.

\section{B. A Proposed Alternative for Section 5K2.13 Departures: Back to the Basics-Cognitive Ability}

This Comment has demonstrated that the term volitional impairment, as it is commonly understood and utilized, is inaccurate and misleading. It does not represent literal involuntariness, and its use by sentencing courts is likely to severely frustrate Congress's main objectives for federal sentencing reform. But, if volitional impairment cannot be a touchstone for section $5 \mathrm{~K} 2.13$ departures, then what should such departures be based upon? The answer is to continue to rely on the usual measure of defendants' mental capacities, namely the standard test for cognitive ability. ${ }^{176}$

Concentrating solely on a defendant's ability to reason, or to appreciate right from wrong, is preferable over trying to assess volitional impairment on many levels. First, all of the cases which raise the greatest perceived need to depart under volitional impairment theories could also be grounded on cognitive impairment. Recall the typical hard choice scenario, for exam-

173 See supra Part III (explaining how people miscomprehend the true meaning of the term).

174 See United States v. McBroom, 124 F.3d 533, 548-49 (3d Cir. 1997) (discussing limitations on potential abuse); see also supra note 159 and accompanying text.

${ }^{175}$ See supra notes 166-71 and accompanying text (describing a number of undesirable examples in which a judge may conceivably depart downward pursuant to section SK2.13).

${ }^{176}$ See Daniel M'Naghten's Case, 8 Eng. Rep. 718, 722 (H.L. 1843) (noting that diminished mental capacity exists where the defendant did not know the "nature and quality of the act he was doing; or, if he did know it ... he did not know he was doing what was wrong"); see also supra notes 17-18 and accompanying text. 
ple. ${ }^{177}$ In such cases, a defendant wants to do something that she knows she should not do, yet she feels compelled to do it anyway because the pain of not doing it will cause dysphoria. ${ }^{178}$ Arguably, it is "irrational to want to produce unjustified harm so intensely that failure to satisfy that desire will create" intolerable internal suffering. ${ }^{179}$ Thus, the inquiry may be easily redefined as one focusing on rationality, rather than confounding things with a concern over volitional impairment.

"Moreover, in a very small class of cases, such as kleptomania or necrophilia, the agent's goal-described as theft for no reason or sexual desire for the dead-may simply seem unintelligible or 'inappropriate' for any rationally motivated human being." ${ }^{180}$ That the hardest volitional impairment cases ultimately may be collapsed into questions of cognitive ability has led Professor Morse to conclude that "[o]ut-of-control agents should sometimes be excused, but not because they do not choose what they do. These cases are better analyzed directly in terms of ordinary justifications for excusing [or mitigating] conditions, such as irrationality and coercion ...."181

Emphasizing the defendant's ability to reason is simply a purer and less-problematic approach to the ultimate question being asked in a section $5 \mathrm{~K} 2.13$ analysis, namely, does the defendant suffer from reduced mental capacity to a significant degree so as to justify mitigation of punishment? Where there are no rationality concerns, a volitionally impaired defendant will be seeking mitigation for conduct that in actuality was voluntary and intentional. No matter how tragic the surrounding circumstances might be, and in spite of legitimate medical diagnoses, the actions will generally be the product of a free and operative will. ${ }^{182}$ Thus, unmitigated punishment will be both appropriate and morally justified. ${ }^{183}$ Furthermore, whereas departures based on volitional impairment may frustrate federal sentencing objectives, ${ }^{184}$ mitigation based on rationality defects is well-established in the law and is wholly compatible with any theory of criminal punishment.

177 See supra notes 61, 104-06 and accompanying text (revisiting as a hard choice, case six from Part III.A: "[S]omeone offers you something you want even more than not to raise your leg if only you raise it, so you do.").

${ }^{178}$ See supra notes $107-10$ and accompanying text.

179 Morse, supra note 27, at 1634.

180 Id.

181 Id. at 1605.

182 See supra Part III.B.5 (maintaining, for example, that hard choice defendants really do have a choice).

${ }^{183}$ See supra Part IV.A.1 (explaining that because people have free will, they bear moral responsibility for their crimes, and thus their sentences should not be reduced).

${ }^{184}$ See supra Part IV.A.2. 
Because the standard for cognitive impairment is widely understood and has been applied by federal courts for some time, reliance on it also avoids the potential abuses of discretion presented by allowing sentencing courts to consider volitional impairment as a basis for departure. ${ }^{185}$ As long as the defendant is able to appreciate the wrongfulness of her conduct, sentencing judges will not be able to consider whatever may have possibly "compelled" the defendant to engage in the reproachable conduct. At least for purposes of section $5 \mathrm{~K} 2.13$ departures, that inquiry would be irrelevant, and uniformity in sentencing would be better protected from serious floodgate concerns.

Exclusive reliance on a defendant's cognitive ability in the context of section $5 \mathrm{~K} 2.13$ departures is also preferable because such an approach would be consistent with the related federal insanity defense. Congress expressly discarded volitional impairment for purposes of an affirmative insanity defense through passage of the IDRA. ${ }^{186}$ By rejecting a volitional prong as part of the insanity test, Congress demonstrated its lack of confidence in psychologists' and others' capacities to measure volitional impairment in defendants with any degree of reliability and accuracy. ${ }^{187}$ These important concerns do not dissipate for purposes of federal sentencing, and there remains no credible way of measuring volitional impairment.

In light of the foregoing points, it came as a surprise that the Commission embraced the Third Circuit's reasoning in McBroom without reservation. The Third Circuit stood virtually alone in permitting a reduced mental capacity departure to be based exclusively on a defendant's asserted volitional impairment. ${ }^{188}$ Moreover, the Commission had addressed the question on several occasions, rejecting proposals to include a volitional prong within section 5K2.13 multiple times in the past. ${ }^{189}$ Nevertheless, the Sentencing Commission has issued its revisions, and it is now up to Congress to remedy the situation.

Every other circuit that had ruled on a sentencing departure pursuant to section $5 \mathrm{~K} 2.13$ considered a defendant's cognitive ability to reason as the

${ }^{185}$ See supra Part IV.A.3.

186 See supra note 28 and accompanying text (discussing the IDRA).

187 See supra note 27 and accompanying text (noting that psychologists do not have sufficient confidence in their own ability to accurately measure volitional impairment).

188 The Third Circuit realized its isolation, noting that: "It thus appears that, for some of our sister courts of appeals, an individual's inability to reason or to absorb information in the usual way is [the sole basis for section $5 \mathrm{~K} 2.13$ departures] .... [H]owever, we cannot agree to such a narrow reading of the guidelines." United States v. McBroom, 124 F.3d 533, 547 (3d Cir. 1997).

189 See supra note 14 and accompanying text. 
"sine qua none of reduced mental capacity." I90 In United States v. Edwards, ${ }^{191}$ for instance, the D.C. Circuit rejected the defendant's arguments that mental capacity has a meaning apart from intellectual capacity. ${ }^{192}$ Likewise, in United States v. Barajas-Nunez, ${ }^{193}$ the Sixth Circuit concluded that "diminished mental capacity is found where a defendant's condition affects his ability to process information or to reason." 194 The Fourth Circuit followed suit in United States $v$. Withers, ${ }^{195}$ where it held that a defendant was ineligible for a downward departure because she failed to show that her depression rendered her unable to process information or to reason. ${ }^{196}$

In United States v. Johnson, ${ }^{197}$ that Sixth Circuit steadfastly refused to depart pursuant to section 5K2.13 absent any showing of cognitive impairment of the defendant. ${ }^{198}$ There, a senior bank executive pleaded guilty to mail fraud in connection with a scheme to defraud his bank of millions of dollars. He had been diagnosed with "Severe Adjustment Disorder," which stemmed from prior negative personal experiences and which he claimed had caused him to engage in the illegal activity. ${ }^{199}$ In rejecting the defendant's argument for departure, the court reasoned that a defendant who "displayed considerable mental agility in his professional and personal affairs" was able to process information and to reason such that he was ineligible for a section $5 \mathrm{~K} 2.13$ departure. ${ }^{200}$ Moreover, the court added that such a case "does not present a situation 'sufficiently unusual' to justify [a reduced mental capacity] departure."201

Applying the traditional standard for reduced mental capacity in McBroom would obviously have produced a different outcome regarding the decision to depart. ${ }^{202}$ This fact, coupled with the defendant's tragically

190 McBroom, 124 F.3d at 547.

19198 F.3d 1364 (D.C. Cir. 1996), cert. denied, 117 S. Ct. 1437 (1997).

192 See id. at 1371 ("If such a psychological or behavioral disorder serves as the basis for the [diminished capacity] departure, however, there must be an accompanying inability to reason.").
19391 F.3d 826 (6th Cir. 1996).
194 Id. at 831.
195100 F.3d 1142 (4th Cir. 1996), cert. denied, 117 S. Ct. 1282 (1997).
196 See id. at 1148 ("Most importantly, there was no evidence that Withers' depression affected her ability to reason or process information.").

197979 F.2d 396 (6th Cir. 1992).

198 See id. at 400-01 (holding that the defendant's ability to reason makes him ineligible for a downward departure under section $5 \mathrm{~K} 2.13$ ).

199 See id. at 400.
200 .
Id. at 401.

201 Id.

202 In fact, the sentencing judge at the trial level initially refused to depart under the cognitive ability standard. The case was appealed to the Third Circuit on the grounds that the 
disturbing personal background, ${ }^{203}$ may have been what ultimately swayed the Third Circuit to reverse the sentencing court and to introduce volitional impairment into the realm of section $5 \mathrm{~K} 2.13$ departures. However noble that intent, the Commission's adoption of the McBroom standard must ultimately be rejected on many grounds, as this Comment has demonstrated. Instead, a better approach is to focus solely on a defendant's ability to appreciate the wrongfulness of her conduct, and to hope that those who are rational seek help in maintaining their self-control, or else suffer the rightful consequences.

\section{CONCLUSION}

The Commission was ill-advised to introduce a standard as unclear and with as troubled a history as "volitional impairment" into the ambit of section 5K2.13 departures. Such a move will likely lead to inadvertent abuses of discretion by sentencing courts that might mitigate sentences on the misperception that agents were metaphorically out-of-control, and thus, somehow less culpable. It is also a step toward reversing the general trend away from considering volition as a factor in any federal case.

In light of these concerns, a substantially better approach to sentencing departures based on reduced mental capacity under the Guidelines is to rely exclusively on a determination of the defendant's cognitive ability. Where a defendant possesses the ability to reason, that is, to appreciate the wrongfulness of her behavior, then to mitigate her sentence based on volitional impairment would not only frustrate key sentencing reform objectives, but would also be morally irresponsible. It is now up to Congress to once again assume the lead in rejecting a standard as unreliable as volitional impairment once and for all.

district court should not be constrained to this analysis alone, but should have also been able to consider volitional impairment under section 5K2.13. See supra notes 10-13 and accompanying text (detailing the reasons for the district court's refusal to depart).

${ }^{203}$ See supra note 4 and accompanying text (describing the abuse McBroom suffered as a child, his bouts with drugs and alcohol, and his states of depression). 
